\title{
"STRANGERS IN THE HOUSE"
}

\author{
THE MAORI LANGUAGE IN \\ GOVERNMENT \\ AND THE MAORI LANGUAGE IN \\ PARLIAMENT \\ 1865-1900
}


Published by the Victoria University of Wellington Law Review 2001

ISBN 0-475-11092-7

Printed by Stylex Print, Palmerston North, New Zealand 


\section{Contents}

Introduction $\quad 2$

Enactments Particularly Affecting the Maori Population 1844-1864 4

Fitzgerald's Statement on Native Affairs, 1862

The Origins of Native Representation 1865-1868 8

The Standing Orders of the House, 1865

The Standing Orders of the Legislative Council, 1867-1900 11

The "Strangers in the House": Maori Members' Speeches 1868-1870 14

Representation in the Legislative Council $1872 \quad 18$

Ko te Pire Tuatahi - The First Bill in Maori 21

The Waka Maori (1971-1877) and the Wananga (1874-1878) 25

Translations of Bills and Acts from 1873 to $1877 \quad 27$

Compendia of Separately Printed Bills and Acts 1878 to 1883

Acts Affecting the Native Race 37

Availability of Bills in Maori 1883-1887 39

Trouble with Neologisms, or Legislative "Maorish", 1886-1888 41

Compendia of Acts and Bills from 1888 to $1900 \quad 43$

Nga Korero Paramete: Maori Members' Speeches 1876-1906 46

$\begin{array}{ll}\text { Conclusion } & 48\end{array}$

Description of Plates

Plate I The Native Lands Act 1865

Plates II and III The Maori Representation Act 1867

Plate IV The Native Lands Frauds Prevention Act, 1870

Plate V The Timber Floating Act, 1873

Plate VI The Native Councils Bill, 1872

Plate VII The Maori Representation Acts, 1867 and 1872

Plate VIII The Sheep Act, 1879 (Extracts) 53

Plate IX The Maori Representation Bill, 1879

$\begin{array}{lll}\text { Plate X The Qualification of Electors Bill, } 1879 & 54\end{array}$

Plate XI Native Land Acts (in English and Maori) ... 1888

Plate XII Nga Korero Paremete 55 
MAORI LANGUAGE IN GOVERNMENT 


\title{
"STRANGERS IN THE HOUSE": THE MAORI LANGUAGE IN GOVERNMENT AND THE MAORI LANGUAGE IN PARLIAMENT $1865-1900$
}

\author{
Phil Parkinson*
}

The Treaty of Waitangi conferred upon Her Majesty's new subjects "all the rights and privileges of British subjects" and that included, in theory, the right to be represented in the infant government. In practice, however, the right of Maori to vote in elections was not taken seriously until 1858 and the presence of formally elected members in the House of Representatives was not achieved until August 1868. When they did speak in 1868 the first four Maori members spoke in Maori, and no adequate provision was made for the translation of their words, or for the words of other members to be translated for them. The proceedings of the House were not printed in Maori and the Maori members' speeches were not translated except when it suited the government of the day.

Over the next few decades after 1868 there was only an irregular compliance with the standing orders of the House of Representatives and the Legislative Council that Bills and Acts be prepared in both Maori and English for the better information of "Her Majesty's subjects of the Native Race". This study traces the extent of the use of the Maori language in the House and in the Council and points to a large number of extant Bills and Acts in Maori as well as to the large number which have not survived but which are referred to in the New Zealand parliamentary debates. These littleknown texts deserve recognition as expressions of legislation in an indigenous tongue reflecting indigenous concerns but they have usually been disregarded in a European-dominated General Assembly.

* Librarian, Research Centre, Alexander Turnbull Library, Wellington. 


\section{INTRODUCTION}

The introduction of British systems of administration, bureaucracy, law and governance to New Zealand after 1840 has been copiously studied, particularly in its constitutional aspects, but the study of the expression of British law in the indigenous language of New Zealand has comparatively been neglected. ${ }^{1}$ It is often unrecognised that some constitutionally and legally significant texts first appeared in published form in Maori and were only later published in English $^{2}$ while other significant texts such as the Proclamations of Sovereignty in 1840 and the Proclamation of New Zealand as a separate Colony in 1841 appeared only in English. In a few cases only were such documents issued in both Maori and English. ${ }^{3}$ Bilingualism as an experiment in government in New Zealand was abandoned at time of crisis during the Northern War of 1845-46 and when war

$+\quad$ This essay is an outgrowth from the Early Maori Imprints Project in the Alexander Turnbull Library. The works in the Maori language described in 1924 by $\mathrm{H} \mathrm{W}$ Williams in his Bibliography of Printed Maori to 1900 (Dominion Musuem Mongraph No 7, Dominion Museum, Wellington, 1924) have been re-investigated, leading to the discovery of many dozens of official publications in Maori not known to H W Williams. These will all be described in the forthcoming work Early Maori Imprints. References here to Early Maori Imprints are indicated by "EMI". References to A G Bagnall's New Zealand National Bibliography (1980) are given here as "Bagnall".

In a separate paper "The Path of the Perfected Law" the use of the Maori Language in the Government of New Zealand from 1840 to 1865", there is an outline of the key developments in the production and diffusion of published legal documents issued by the Government during the Governorships of Hobson, FitzRoy, Grey and Gore Browne through to the "Kohimarama Conference" of 1860, the accession of the second Maori King (Tawhiao) at that time and the breakdown of the "Covenant" between the tribes and the Government in the following year which saw the return of Grey and the commencement of the New Zealand Wars.

1 For example James Belich's Making peoples: a general history of the New Zealanders from Polynesian settlement to the end of the nineteenth century (Allen Lane, Auckland, 1996) says little about Maori representation. The general review of the history of Maori representation by W K Jackson \& G A Wood, "The New Zealand parliament and Maori Representation" (1964) 11 Historical Studies, Australia and New Zealand, 383 is concise and useful but says nothing at all about the use of the Maori language. Alan Ward's $A$ show of justice: racial "amalgamation" in nineteenth century New Zealand (2 ed, Auckland University Press, Auckland, 1995) 208-219 is the best treatment but even it does not pay attention to the use of the Maori language in politics. See also MPK Sorrenson "A History of Maori Representation in Parliament" in "Report of the Royal Commission on the Electoral System" [1986] AJHR H3.

2 The "Declaration of Independence" of 1835 and the Treaty of Waitangi in 1840 are obvious examples.

3 Singular among these is the Proclamation of 2 May 1840 concerning military supplies citing 2 \& 3 Vict Cap 5 (19 April 1839) "An Act for the punishment of mutiny . . " which was translated and printed in Maori two days later by the missionary printer William Colenso. The Proclamation of 2 May in English is Bagnall, 4039 and the Maori text is Bagnall, 4039a, the latter being Williams, 54. 
threatened in the Hutt Valley in 1846. With the restoration of peace Maori texts began to appear again.

After the Wars a new period in New Zealand's history began in which novel attempts were made to further integrate Maori into political life via appointment or election of Maori to political office. The use of the Maori language in the governance of New Zealand then came to the fore, giving the title to this essay. The record of the debates in the Legislative Council and in the House of Representatives on the subject of Maori representation is not well known and neither are the Maori texts of the Acts and Bills in which Maori sought to secure and to increase their political advancement. This study charts the development of Maori participation in the House and the Council through a record of the printing and circulation of documents of particular concern to Maori dealing with Maori language, land rights and other matters. It also illuminates the reasons for the persistent failure of the two Houses to act upon their own standing orders in respect of the timely publication of legislation in Maori.

The introduction of the Maori language into Parliament was in part a stratagem to show that the Maori language was obsolescent and that if Maori wanted to get ahead in the world they would need to learn English. A few politicians, the most notable being Walter Mantell, fostered the effort to make the laws of New Zealand available to the native population. As Governor in the late 1850s Gore Browne had been supportive of efforts to accustom Maori to British legal processes, but the great impediment was that there were vast differences in the manner in which two different mentalities, Maori and British, used orality and literacy to communicate with each other. The Maori custom was reliant upon memory of words said and deeds done; but the Pakeha wrote everything down and that put them at an advantage until Maori developed articulate, literate and bilingual scholars too.

Between 1840 and 1865 the Maori language was hardly used in Government except for occasional proclamations by the Governor, as much of the administration of government rested in the hands of the Native Secretaries and Land Purchase Agents. Despite acknowledgement of the Treaty of Waitangi and some sort of apprehension from as early as 1840 that bilingual and bicultural discourse was essential to the effective functioning of the Government, only a few brave attempts were made to recognise the Maori language as a necessary language of Government. Some officials (such as the philosophically inclined Governor Grey) learned Maori out of antiquarian interest but most did not. The introduction of Maori members into the House of Representatives in 1868 was intended to persuade Maori that it would be better if everyone spoke English but it had an unintended effect; it left Maori to be represented by "tame kaka" who could not understand the proceedings going on around them. The representation was a sham perpetuated for the rest of the century by four token Maori members. 
The New Zealand Government and administration has, in principle, two official languages, recognising the Maori language ("the New Zealand language" as it was originally and more properly called) as a taonga (a cultural property) protected by the Treaty of Waitangi. ${ }^{4}$ But in practical terms the Maori language remains of doubtful utility as a vehicle of informed political discourse. Why this should be so is explored in this paper.

\section{ENACTMENTS PARTICULARLY AFFECTING THE MAORI POPULATION 1844-1864}

Before 1858 there had been a large number of Acts and Ordinances "particularly affecting" the Maori population, ranging from the Native Trust Ordinance and Unsworn Testimony Ordinance 1844 to the New Zealand Native Reserves Act 1856. None of these had been printed in Maori and the Government appears not to have published any explanations of them in Maori either. The first Acts of the Government to be printed in Maori were the Native Districts Regulation Act 1858 and the Native Circuit Courts Act 1858 which were issued together in pamphlet form ${ }^{5}$ as well as being explained in the Maori Messenger of 15 September $1858 .^{6}$

Why these two Acts were printed in Maori but others were not is not clear, but it is possible that Browne was more sensible than Grey of his Treaty obligations. For several years the printing of Maori texts of enactments remained haphazard. ${ }^{7}$

The principal attempt of the Governor to introduce Maori participation in the affairs of Government was the Kohimarama Conference of 10 July to 10 August $1860 .^{8}$ Enthusiasm

4 The long title of the Maori Language Act, 1987 is: "An Act to declare the Maori language to be an official language of New Zealand, to confer the right to speak Maori in certain legal proceedings, and to establish Te Komihana Mo te Reo Maori and define its functions and powers." The preamble to the Act states "Whereas in the Treaty of Waitangi the Crown confirmed and guaranteed to the Maori people, among other things, all their taonga: And whereas the Maori language is one such taonga: ..." This Act was translated into Maori and published by the Attorney-General, but the translation was not enacted by Parliament (see NZ Laws Statutes 1987 pp 2446-2461). The formal name of the Commission was altered to "Te Taura Whiri $i$ te Reo Maori" by the Maori Language Amendment Act 1991. The amending Act was not translated.

5 Two Acts passed by the General Assembly of New Zealand, 1858 relating to native affairs (W C Wilson for the New Zealand Government, Auckland, 1859). See Williams, 308. The two Acts are printed on facing pages of English and Maori.

6 Vol 5 no 15.

7 The most likely explanation is that the Governor's brilliant and liberal idea was more difficult in the execution than anyone had realised. Consequently neither the Native Schools Act 1858 nor the Native Territorial Rights Act 1858 nor the Native Council Act 1860 nor the Intestate Native Succession Act, 1861 were printed in Maori. The Acts not specifically affecting Maori were not translated. 
for involving Maori in legislation took a setback with the fighting in Taranaki, and Gore Browne was dismissed to be replaced by Grey at the end of 1861. Grey then announced his scheme for native self-government using a system of tribal runanga. ${ }^{9}$ Extracts of the Native Circuit Courts Act 1858 were printed in Maori in 1862 along with Oaths of Allegiance as part of Grey's plan for native self-government. The first of these district runanga was established in Tai Tokerau and promised much at first but enthusiasm for it soon waned. ${ }^{10}$ The experiment was not followed elsewhere.

\section{FITZGERALD'S STATEMENT ON NATIVE AFFAIRS, 1862}

A growing realisation that the promises of the Treaty of Waitangi had been broken, despite a decade of Government self-congratulation about it, had led to a new and critical attitude towards native policy. In this Walter Mantell (then Minister without portfolio) and J E Fitzgerald took prominent parts. On 7 August 1862 the House of Representatives considered the motion by Fitzgerald: "That in the adoption of any policy, or the passing of any laws affecting the Native race, this House will keep before it, as its highest objective, the entire amalgamation of all Her Majesty's subjects in New Zealand into one united people." 11 Fitzgerald then moved: "That this house recognises the right of all Her Majesty's subjects of whatever race within this colony to a full and equal enjoyment of civil and political privileges" and further moved: ${ }^{12}$

That a recognition of the foregoing principle will necessitate the personal aid of one or more Native Chiefs in the administration of the Government of the Colony, the presence of members of the Maori nobility in the Legislative Council, and a fair representation in this House, of a race which constitutes one-third of the population of the Colony.

8 Proceedings of the Kohimarama Conference (W C Wilson for the New Zealand Government, Auckland, 1860). See Williams, 317.

9 Untitled "Statement on Native Policy, 1861" in Maori (not in Williams, to be described in EMI), also printed in (16 December 1861)Te Karere Maori vol 1 no 18/19 and in English in Governor and Ministers "Minutes by Ministers on the Position of the Colony of the Date of the Arrival of St George Grey" [1862] AJHR E2. The "new institutions" are described by Ward in A Show of Justice (Auckland University Press, Auckland, 1995) 125-133.

10 Ko nga korero o te runanga tuatahi o te takiwa ki Tokerau. (W C Wilson, Auckland, 1862). See Williams, 354. Also printed in (23 May 1862)Te Karere Maori vol 2 no 10, 13-22 ["The first Maori Parliament or District Runanga"].

11 [1862] JHR 46 (7 August 1862). Richardson moved the omission of the words "or the passing of any laws" but this was defeated.

12 [1862] JHR 46 (7 August 1862). See also M Fitzgerald [1861-1863] NZPD 483-494 and 505-513 for the report of the debate. The Fox Ministry resigned on 28 July 1862 over the crisis in native affairs. 
William Colenso, the de facto "Government Printer" printer of 1840, missionary (defrocked in 1852), translator and in 1862 the Member in the House of Representatives for Napier, suggested in the same debate: ${ }^{13}$

That on reading that portion of [the motion] which referred to the presence of the Maori nobility in the Legislative Council he had thought [Fitzgerald meant that the nobility possessed such qualities as to make them suitable as members of the Council or that the Pakeha members of the Council lacked such qualities]. Now the cry out-of-doors was that the natives were better represented by the whites. In his opinion they were fairly represented-if not too much so. Did they not vote at elections? Could they not increase their number of electors to almost any amount? [. . . ] If they felt they were not fairly represented, let them by all constitutional means seek to become better represented. But the truth was that the natives cared very little about it. [. . . In conclusion he would say that he looked upon this scheme as Utopian and premature, and by no means a step in the right direction. A long scheme of education was first necessary before they could put the natives in the position proposed. [...] he felt assured it would prove utterly impracticable in the working; and then they would only have another stumbling block, and increase of distrust, for by carrying it it could only hold out vain delusive hopes which could never be realised, and so become a new source of discontent to the Maori people.

Hugh Carleton, then the Member for Bay of Islands, and formerly the editor of the Anglo-Maori Warder, which had printed a Maori column opined that: "If it meant that natives should take part in the Government so soon as they were fit for it, and no sooner, no one could object; if it meant more than that, it would not be agreed to, for it was in contradiction to the resolution of 1858 [. . . " (which Carleton had moved ${ }^{14}$ ): ${ }^{15}$

Resolved that in the opinion of this House, the New Zealand Government ought to endeavour to obtain an opinion from the law officers of the Imperial Government, of claims to vote preferred by aboriginal natives under the 7 th and 42 nd sections of the Constitution Act whether natives can have such possession of any land that is used by them in common as tribes or communities, and not held by them under title derived from the Crown, as would qualify them to become voters under the aforecited sections; this with a view to petitioning the Imperial Parliament, or taking other the proper measures to be relieved from the grave inconveniences and probable dangers to the Government of this country which are to be apprehended should it be found that a large body of men who are destitute of political

13 [1861-1863] NZPD 506-507.

$14 \quad[1858-1860]$ NZPD 158.

15 [1861-1863] NZPD 507. The Law Officers of the Crown had considered the natives altogether disqualified. 
knowledge, who are mainly ignorant of the language in which our laws are written, and among whom respect for the law cannot as yet be enforced have been allowed the right of interference with the enactment of law.

He spoke as a practical man, and asked what they were going to do with the natives when they got them into the assembly. The difference of language alone would render it impossible to carry on the business of the House."

Fitzgerald in reply stated: ${ }^{16}$

What we want is that a higher idea overlying the whole shall get into the minds of the natives-the idea that there is one law for all men in this country. This is the only thing which will solve the great mystery; we must get the Maori to recognise the idea of law-to have confidence in our laws: and one great means to that end is to admit him into this House, and so to persuade him that, if we make laws for him he makes laws for himself and also for us. The time will then shortly arrive when the Maori will have a thorough and entire trust in our laws, and we shall have no difficulty in enforcing them all over the country. [ . . ] The native does not object to the law being enforced; but he resists the idea of being put under submission to another race-a race that has never given him one tittle of law to guide his actions.

When the series of motions was put the House agreed "That this House recognises the right of all Her Majesty's subjects, of whatever race, within this colony, to a full and equal enjoyment of civil and political privileges" and then moved

That a recognition of the foregoing principle will necessitate the personal aid of one or more Native Chiefs in the administration of the Government of the Colony; the presence of members of the Maori nobility in the Legislative Council, and a fair representation in this House, of a race which constitutes one-third of the population of the Colony.

After further debate the House divided and the motion was lost 17 to $20 .{ }^{17}$

The crucially important Native Land Act 1862 was not published in Maori until it was proposed to revise it in 1865. At this point Walter Mantell (at this time again Minister for Native Affairs and Native Secretary) issued a translation of the Act in pamphlet form advising that it was about to be changed. ${ }^{18}$ The effect of the 1862 Act had been to enable Maori to sell their lands for whatever prices they could negotiate. The Act was about to be

16 [1861-1863] NZPD 510.

17 [1861-1863] NZPD 513.

18 Ko nga Ture mo nga whenua Maori, 1862 (Wellington, 1865). See Williams, 352. The Act was printed in Maori only. The English text of the Act of 1862 was already available. The Act was not proclaimed until 1 January 1865 because of the New Zealand Wars. 
amended to make it apply only to those Maori whose lands were not covered by the confiscation Proclamation of December 1864. To enable the Magistrates (at least) to make sense of a spate of legislation, the Government issued a compendium of legislation "affecting the aboriginal inhabitants of New Zealand" in $1864 .{ }^{19}$

In due course the Native Lands Act 1865 emerged from Mantell's successor Fitzgerald, printed in Maori in the same way as the contemporary English text of the Act. ${ }^{20}$ This was the first Act of the New Zealand Parliament to be printed in Maori. It was, however, to remain an isolated example for two years. It was due to Fitzgerald, also, that the Kahiti o Niu Tireni was started as a vehicle for informing Maori of the effects of the legislation affecting them. It was to be a messenger (karere) for the Maori people as the New Zealand Gazette was for the pakeha and the vehicle for all Government communications: "Ko nga kupu katoa a Te Kawanatanga ki nga iwi Maori katoa, ka korerotia nuitia atu ki roto ki tenei pukapuka, a kahore, atu he ara mo te korero."21

\section{THE ORIGINS OF NATIVE REPRESENTATION 1865-1868}

In 1865 the Weld ministry attempted to introduce Maori representatives by appointment to the Legislative Council. A list of the names of fifteen prospective Maori members for the Legislative Council was drawn up. All but three prospects were disqualified on one or more grounds. A Native Representation Bill was drafted and sent to Walter Mantell for his comments. As he explained in the Legislative Council on 5 September 1870:

The fact was that he had steadfastly opposed such a mockery of representation as was introduced under the Act of 1865 . He held in his hand a Bill which was originally proposed by the Weld Government. He was himself asked whether he would suggest the heads of a Bill on the subject, and whether the Bill met his views. His reply was "I so thoroughly object to the principle of this Bill that I would rather not attempt to modify it."

Mantell's opposition was not to the principle of representation in itself, but rather to the means of implementing it; he had voted for Fitzgerald's motion of 1862. After the list had been drawn up, he explained, he had 22

19 A Mackay (comp) A compendium of Ordinances, Acts and Orders in Council. (1864). See Bagnall 4078.

20 Native Lands Act 1865 [Maori]. See Williams, 408. Copies were probably distributed with copies of the "Maori Gazette" Kahiti o Niu Tireni SeeWilliams, 407) which commenced on 31 August 1865.

21 Ko te Kahiti o Niu Tireni, i taia i runga i te mana o te Kawanatanga, 31 August 1865, vol 1 no 1, 1.

22 (6 September 1870) 9 NZPD 517. The draft Bill, with extensive annotations by Mantell is among his political papers ATL MS-Papers-083-225. 
asked what provision would be made that the persons mentioned might be able to take an active part in the proceedings of the Legislative Council. It was thought that they would be satisfied to sit, and vote merely when called upon to do so, but that would not satisfy him. He desired to have them assisted by interpreters, and to have documents printed in Maori, but the Bill ultimately fell through because he would not consent to insult the Maoris by offering them a sham representation. That was the only thing which prevented the three gentlemen to whom he referred getting seats in the Legislative Council, in 1865.

Maori representation came to be introduced first, therefore, via the Maori Representation Act 1867, in the form of the four token Maori seats in the House of Representatives. With the commencement of Maori representation in Parliament in 1868 new issues arose in view of the fact that the Maori representatives could neither read nor speak English and a translation service had to be provided. This also forced consideration of whether parliamentary papers should be available as texts in Maori. There had apparently not been any formal method of prior consultation with Maori about the contents of Bills or Acts.

\section{$V$ THE STANDING ORDERS OF THE HOUSE, 1865}

The draft set of Standing Orders prepared by the Speaker (D Monro) was laid on the table of the House on 26 July 1865 having been "prepared in accordance with the Resolution of the House of the 2nd December, 1863."23 Standing Order 333 stated: "Accounts and Papers are ordered to be printed, whenever it is expedient" but there was no specific provision relating to printing in Maori. On 1 August 1865 Fitzgerald proposed the following motion in the House of Representatives, relative to Maori translations:

That it be a Standing Order of this House that the Speech of His Excellency the Governor at the opening of each session, every Bill introduced into this House in any way affecting the interests or government of the Native race, and all such papers laid before this House referring to Native Affairs as shall be selected by the Printing Committee for that purpose, shall be translated into and printed in the Maori tongue; and that Mr Speaker be requested to appoint authorized translators to translate the same.

After some discussion, which included a suggestion from Sewell that the motion be referred to the Standing Orders Committee, Fitzgerald sought leave to withdraw the motion "as there was a Committee sitting on the Standing Orders". Leave was granted and

23 It was published as Standing Orders and Forms of Proceeding of the House of Representatives relating to Public Business, 1865. See Bagnall, 4154). The copy examined (WTU Pacific Coll, 328.37 NZ Parl Acc No 31963) includes a circular notice by the author David Monro dated 20 May 1865 enclosing "a Draft set of Standing Orders". See Bagnall, 4159. For later editions of the Standing Orders see Bagnall, 4155 (1876), 4156 (1882); and for the translation into Maori, Bagnall 4157 (1880). 
the motion withdrawn. The draft Standing Orders devised by Monro were considered by the House in Committee on 5 September 1865, when Fitzgerald moved: "That the following do stand as orders after printed order 334":

Speeches addressed to the House by His Excellency the Governor, and Bills introduced into the House specially affecting the Maoris, are translated into and printed in the Maori tongue for the information of Her Majesty's subjects of that race.

All other papers are translated into and printed in Maori only by Order of the House upon motion.

This motion was adopted and the revised Standing Orders were agreed to by the House on 7 September after which they were transmitted to the Governor for his approval. ${ }^{24}$ When Governor Grey prorogued the House on 30 October he said:

The measures you have passed affecting Her Majesty's subjects of the Native Race, are evidence of your earnest desire to extend to them, to the full, all the rights and privileges enjoyed and prized by British subjects. By such measures, wisely administered, there is every reason to believe that they will become steadfastly assured that their interests will be zealously guarded by the Legislature, on whom they can rely to secure, by every means in its power, happiness and prosperity to those among them who are peaceably inclined, while those who may unfortunately be led into crime will assuredly discover that a certain punishment awaits them.

These Standing Orders were carried over by motion for the next session. The Select Committee on Standing Orders appointed on 24 July 1868 made an interim report on 21 August 1868 with three pertinent resolutions concerning the conducting of the business of the House in Maori: 25

(3) That it is highly desirable that some simple text-book of Parliamentary Practice be published in Maori, for the benefit of the Maori Members and the instruction of the Maori people.

(4) That Mr Speaker be instructed to make a selection of such Sessional Papers as may appear to him of the greatest interest to the Native race generally, and to have them translated and printed.

(5) That when the Government lays papers on the Table of the House in future, such of them as may be considered of most interest to the Maoris should, unless inconvenient delay should result, be accompanied by a translation in the Native language.

24 This was given in a Governor's Message dated 11 September and received by the House on the next day ([1865] JHR 104, 111 and 119). 
The Standing Orders were translated into Maori in $1880 .{ }^{26}$

\section{THE STANDING ORDERS OF THE LEGISLATIVE COUNCIL 1867-1900}

The Legislative Council maintained its own Standing Orders, the earliest seen being Standing Rules and Orders of the Legislative Council of New Zealand 1867. These state:

316 Speeches addressed to the Council by His Excellency the Governor, and Bills introduced into the Council specially affecting the Maoris, are translated and printed in the Maori tongue, for the information of Her Majesty's subjects of that race.

317 Other papers may be translated into and printed in Maori by order of the Council upon motion.

In practice these Standing Orders were largely ignored by both Houses. In the Legislative Council on 29 July 1868 Mantell sought to correct this situation by moving:

That there be laid upon the table a return setting forth the titles of all Bills specially affecting the Maoris which, since 25th July 1865, have, in accordance with Standing Order No 316, been translated and printed in the Maori tongue, for the information of Her Majesty's subjects of that race; also copies of such printed translations, and of the printed translations of the speeches addressed to the Council by His Excellency the Governor, since the above date.

Speaking to the motion he noted that: ${ }^{27}$

It was quite impossible to say how far the Standing Order had been complied with by the Government, or what had been the idea of past Governments as to what Bills especially affected the Maori population. He must say that he understood the Bills especially affecting the Maori population to mean Bills not merely affecting them directly, but Bills which might be considered likely to affect the Maoris or their interests. Taking this view of the case he could make allowances for a Government with such a Standing Order staring them in the face, and so many Bills constantly being introduced in the Council or originated in the other branch of the Legislature, [...] taking a narrow view as to the Bills pointed out by the Standing Order. But when they got the returns, if they found that the view taken by the Government was too narrow, according to their conceptions, and calculated to leave the natives in ignorance of measures which were being taken concerning them, then it would be for the Council on some future occasion to express its opinion on the wisdom and justice of the course. He would only just glance at a few of the recently passed Acts, copies of which he would like to see in the Native language on the table of the Council. An Act with reference to the compulsory taking

26 Ture whakahaere korero me nga tikanga mahi a te Whare Pootitia mo nga mahi a te katoa (G Didsbury, Government Printer, Wellington, 1880). See Williams, 594; Bagnall, 4157. 
of land was assented to last session, and an attempt was made by some honorable members to exclude some of the Natives from the operation of the Bill. The attempt was, however, unsuccessful. He considered that that Bill should have been held to specially affect the Natives. There was also a Bill passed last session [. . . ] for the purpose of allowing Natives to be members of the House of Representatives and when that was passed, and Native representation commenced, the Disqualification Act was one that it was important to translate into Maori, as specially affecting that event. The Bill for Protection of Animals, which specified certain punishable offences, also affected the Maoris, and it would appear right that its provisions should have been translated into the Native tongue, as the Maoris might otherwise be unintentionally breaking the law. The word which was in the Standing Order to which he referred was not "Acts" but "Bills" therefore the translations of the Acts which had passed the Legislature, was not absolutely required, so as to comply with the Standing Order. The intention seemed to be that before the Bills affecting Natives became Acts they should be translated, in order to allow them an opportunity of seeing the kind of legislation which was proposed. When the returns were laid upon the table of the Council, honourable members would ascertain what had been the opinion of past Governments as to what affected the Natives and what did not. If the Natives were to be made responsible to British laws then they should be allowed to know them.

The Colonial Secretary (Pollen), replying, admitted that he had not even been aware of the Standing Order until Mantell had drawn his attention to it, and that, moreover, he thought that the Council was responsible for carrying out the matter. Colonel Kenny pointed out that Standing Order 316 was absolute rather than permissive (as was for example Standing Order 317) and remarked that "As the Council had no way of carrying out its provisions, it was clear that it was the duty of some one connected with the Government to see that it was done." The motion was agreed to and the return was duly published: ${ }^{28}$

No Bills have been translated and printed for the information of Her Majesty's subjects of both races, since 25th July 1865. The undermentioned Acts of the General Assembly have been translated and printed since that date:- "The Native Lands Act, 1865;" "The Native Schools Act, 1867;" "The Maori Representation Act, 1867." Copies of the above-named Acts are attached hereto. Also, the Speeches addressed by His Excellency the Governor to the Council, in the sessions $1865,1866,1867$ and 1868.

The translations of the Governor's speeches are doubtless the texts printed in Te Kahiti o Niu Tireni, which had commenced publication in 1865. Copies of all three Acts have survived. ${ }^{29}$ As to the meaning of "specially affecting the Maoris" opinions could plainly

29 Respectively Williams, 408, (see Plate I) Williams, 342b; and not in Williams, but to be described in EMI (see Plates II and III). 
differ. Mackay in his Compendium of Official Documents relative to Native Affairs in the South Island (1871) provides a "List of Acts and Ordinances Specially Affecting the Aboriginal Natives of New Zealand" and a comprehensive schedule and analysis listing Acts from 1844 to 1870 , no less than nineteen of them in the period 1865 to $1867 . .^{30}$ These include the three actually printed in Maori, but also such acts as the Native Rights Act 1865 and the Maori Real Restate Management Act 1867 which were not printed in Maori although clearly they ought to have been. Failure to carry out the Standing Orders was plainly a Government matter, as Colonel Kenny had observed. The control of the printing of Bills and Acts in Maori was thus directly a Government responsibility in the hands of the Colonial Secretary.

Until 1868 the practice had been to postpone the printing of Acts until after the end of the parliamentary session, in order to arrange and number them according to subject. As the Clerk of the House wrote to the Speaker on 15 July 1868, this caused delays which were the subject of complaints. The Clerk sought that the Acts might be printed as soon as passed. At a meeting of the Printing Committee in that year the Government Printer, George Didsbury, said that the Printing Office was entirely under the management of the Executive Government and he was under the orders of the Colonial Secretary. In his opinion "it was quite impracticable to devote a portion of the printing establishment to the service of the legislature, as it also did the printing work for Government Departments. "31

The Standing Order, refers to "Bills" rather than to "Acts". Yet while the printing in Maori of Acts was very selective, no Bills at all were printed in Maori until 1872, four years after Maori members took their seats in the House of Representatives. Ironically, therefore, there was no prior consultation in Maori with Maori over the central question of Maori representation itself. It was not until the Maori Representation Bill 1867 was enacted (in the English language) that Maori were to find out what provision the Government had made. A motion that the second reading debate on that Bill be translated and printed in Maori had been withdrawn. Mantell's motion of 29 July $1868^{32}$ is also significant because it closely coincided with the first speeches given in the House of Representatives by the newly elected Maori members.

30 A Mackay Compendium of Official Documents relative to Native Affairs in the South Island (Government Printer, Wellington, 1871) vol 2348-371. See Bagnall, 3286.

31 NA LE 1 1868/2 Printing Committee Minute Book, 1868.

32 (29 July 1868) 2 NZPD 141. 


\section{THE "STRANGERS IN THE HOUSE": MAORI MEMBERS' SPEECHES 1868-1870}

The infrequent participation of the four Maori members in the debates is hardly surprising in the circumstances. The House met on 9 July 1868 and the new Maori members first spoke in the House on 4 August. But before they could do so an interpreter was needed and it was objected that that Official Interpreter would be a "stranger in the House". Richmond pointed out that "having passed an Act giving nominal representation to their Maori Fellow-countrymen, it would be rather inconsistent if they were to allow any mere matter of form to stand between those members and their natural constitutional desire." Reynolds, however, rose "to point out the absurdity of their allowing members in that House who did not understand English, and who could not therefore give their votes according to knowledge. He thought it should be one of their rules that no interpreter should enter the house." Richmond's motion to request the Speaker to summon the interpreter to the House to translate was carried. ${ }^{33}$

In his first speech in the House the first member for Western Maori (Mete Kingi Paetahi) is recorded as saying through the interpreter "I have not been able to understand what has taken place in this House since I took my seat in it"34 and on the second occasion on which he spoke (13 August) he said (through the interpreter) ${ }^{35}$

There is one thing I am dark about in this Assembly, although the words spoken by the Assembly are very good. The interpreter has told me some of the words spoken by you, and they are very clear: but there is still one thing concealed by you. The papers are only printed in your own language; your words are not sent to the Maori people, that they may see how good they are; but we, the Maori, having seats in this House see how good your words are. Your manner of conducting matters, both as regards Maoris and Europeans, is very good. That is the only fault I have to find, that the papers and newspapers are not printed in the Maori language so that they may go to the Maori people in the same way as they now go to Europeans.

He spoke on only three further occasions during the session, in each case about his personal actions. The member for Eastern Maori (Tareha Te Moananui) also speaking through an interpreter, spoke briefly on a single occasion during the session. Dissatisfaction with the situation of the Maori members was expressed by one of them ( $F$ Nene Russell, Northern Maori), who, in the words of another member, "not only

33 (4 August 1868) 2 NZPD 258-259.

34 (4 August 1868) 2 NZPD 271.

35 (13 August 1868) 2 NZPD 466. 
understood Maori but also spoke English as well as any of them". ${ }^{36}$ The Maori Representation Act 1867 had included the restriction that only persons of Maori descent could be Maori representatives. Russell proposed to remove this restriction in his motion of 14 August, to allow Maori to elect Europeans to represent them: ${ }^{37}$

He said that anyone who had been present during the session must have plainly seen that if the representation of the Maori people was to be anything beyond a sham they must be entitled to return Europeans in whom they had confidence. By the present system they returned men having rank amongst themselves, and who amongst the Maoris were probably as good orators as most Europeans, but it was easy to see that they did not understand what was going on or said, and were often called upon to vote on questions of which they were utterly ignorant; and even when matters were brought in concerning the Maori race, they were as likely to vote on the wrong side as the right. They felt as much as anyone in the House, that unless the Maoris were allowed either to have a separate Assembly for themselves, to which all questions relating to Maori matters should be referred, or be allowed to elect persons of the European race to that House, they had better not be represented at all; for sitting in those seats the whole Maori race became responsible for the acts of that Assembly. [. . .] The present election showed that most unfortunately the chief in the place of nomination was the only one that had a chance of being returned, and the consequence was that many of the largest and most influential tribes in the country were not represented at all, as he might mention in the instance of the Arawas, Waikatos and Thames tribes. He would read an extract from the report of Mr Edward Williams, Resident Magistrate at Waimate, Bay of Islands, in practical evidence of what he had just brought forward:-

During a conversation I had with Abraham Taonui on the subject of Maori representation, the following remarks were made:- He first wished to know the motive for introducing Maori members into the House. When told it was that Maoris might have a voice in the Legislature he replied: "Very good; you say that there are to be four Maori members and twenty Pakehas; what are these four to do among so many Pakehas; where will their voices be as compared with the Pakeha voices? How are they to understand anything the Pakehas say? or the Pakehas anything the Maoris say? Is each man to have his interpreter by his side; if not are they to listen to the Pakeha talk without understanding a word that is spoken? Speak without being understood? Give the Aye when asked to do so without knowing what they give the Aye to; and, by-and-by, when some new Act bearing upon the Maoris is brought into operation, be told, oh, you assisted in passing it! It will not do. Now, if we had been allowed to return some Pakeha in whom we could place confidence, it would have been a better arrangement, but the present one will not answer."

37 (14 August 1868) 2 NZPD 493. 
Pakeha members allude to a motivation of the 1867 Act as forcing Maori leaders to become conversant with English, and that the Act was viewed as a temporary expedient to expire in 1872 once this was achieved. As Reynolds said ${ }^{38}$

special representation [should] be done away with, except in cases of Maori representation, which must, according to the Act, be carried on for four years. After that period the Maori population would be in the position to be represented in the same manner as Europeans by enrolling themselves on the electoral roll.

The essentially token role of the four Maori members is all too clear in the patronising remark of William Fox that all members: ${ }^{39}$

must have been gratified at the manner in which the Maori representatives had conducted themselves in the House, and at the total absence of all obtrusiveness on their part, considering the annoyance they must have experienced at not being able to understand the language in which debates were carried on.

The inability of Mete Kingi and Tareha to understand English is noted by Mete Kingi on other occasions. For example, in a debate on the financial statement on 19 July 1870 he says: ${ }^{40}$

I have been here for four weeks in the House and have said nothing. Tareha and I have been in this Parliament for three years. Although, perhaps, we may not understand all the matters which you discuss, still, my opinion is that we may be allowed to say a few words on Maori matters. We are not familiar with your language, and therefore cannot follow all the points which are adduced in respect of the laws. It is through our not having any knowledge of your language that we have been silent during the time the Assembly has been sitting. [. . . W We hear from the Maoris that the European members do not uphold the views which we bring forward, and that some Maoris have represented that Mete and Tareha are no use in the Assembly, that we say nothing and they hear nothing of what we say. I rather agree with that, because 1 do give advice when I speak and you do not believe in it, but you carry matters your own way.

Mantell (in the Legislative Council) successfully moved another motion concerning Standing Order 316 on 5 September $1870:{ }^{41}$

\footnotetext{
38 (14 August 1868) 2 NZPD 497.

39 (14 August 1868) 2 NZPD 499.

$40 \quad$ (19 July 1870) 7 NZPD 513.

$41 \quad$ (5 September 1870) 9 NZPD 514.
} 
That in order that due effect may be given to Standing Order No 316, providing that all Bills introduced into the Council, specially affecting the Maoris, be translated, printed and circulated in the Maori tongue, for the information of Her Majesty's subjects of that race, it is, in the opinion of this Council essential that all Bills of the above character, which the Government may propose to introduce during next session, be prepared, translated, printed and distributed among the Maoris, at a period anterior to the next meeting of the Assembly, sufficient to enable Her Majesty's subjects of that race to express their views and wishes thereupon immediately after such meeting.

The Colonial Secretary (Gisborne), for the Government, pointed out practical difficulties: ${ }^{42}$

Even supposing that all Bills were decided upon during the recess, it would be very difficult, in the circulation of those Bills, to prevent the Maoris from confusing them with Acts which had been passed by the Assembly; besides it was almost impossible for the best Maori scholar to translate those Bills literally, or to explain them in a way that would be intelligible to the Natives. The responsibility would be thrown on the Government of telling the Natives the meaning of every clause, which would amount to a judicial interpretation. It was only right that he should draw atttention to those inconveniences, although they might, perhaps, be less than those of not publishing the Bills at all. The proper solution of the difficulty appeared to be to have Maori representation in Parliament, because the Maoris through their representatives, very soon understood the legislation. [...] It was impracticable to distribute all the Bills before the commencement of the session. He, however, fully admitted the principle of giving the Natives an opportunity of expressing an intelligent opinion upon measures which specially affected them.

\section{Whitmore responded that the Colonial Secretary ${ }^{43}$}

had not recognised what was now universally recognised throughout the country - that the Maori representation was a failure. There was no vote which he had ever given which he so much regretted as his vote in favour of that law. Not only did the Maori members not understand the practice of legislation, but they did not understand the different Bills which were brought down before the House. The present representation was unsatisfactory to the Maoris themselves, and the Natives of the East Coast had expressed themselves as being dissatisfied with the conduct of their representative, Tareha, and asked that he should cease to represent them in Parliament.

42 (6 September 1870) 9 NZPD 515.

43 (6 September 1870) 9 NZPD 515. 
Sewell asked that Mantell allow his motion to be altered to refer to Acts rather than Bills. Fraser said Maori representation was "one of the greatest shams that was ever introduced into the Colony." 44 Paterson, who had supported McLean's Maori Representation Bill said he now considered it "a mistake altogether, and that the Natives were not yet in a position to take their place in the Legislature. As to printing Bills in the Native language, he thought any such attempt would prove as abortive as the other had been." 45 Mantell in reply said that he did not agree that the Natives would mistake Bills for Acts. He felt that the Colonial Secretary underrated Native intelligence. Furthermore making clauses intelligible was a more general difficulty since many were unintelligible even in English. He reiterated the main point that his motion was based on Standing Order 316 and had nothing to do with Maori representation as such. ${ }^{46}$

As to the Maori Representation Act itself, he had reason to believe from what had fallen from the Maoris themselves, that they regarded it as rather an insult than anything else, and there was no doubt we should regard such a measure as an insult to our intelligence if a Maori Parliament proposed it and allowed it to be passed in that way. The gentlemen so elected were looked upon merely as officers of the Government, and they had all the confidence reposed in them which in that character they could be expected to receive.

\section{REPRESENTATION IN THE LEGISLATIVE COUNCIL 1872}

Mete Kingi was defeated in the election at the end of 1870 and the other three Maori members all retired. They were succeeded by Wiremu Katene (Northern Maori), Wiremu Parata (Western Maori), Hori Kerei Taiaroa (Southern Maori) and Karaitiana Takamoana (Eastern Maori). The new Maori Members of the House of Representatives apparently spoke in Maori, sharing one interpreter between the four of them and took a much more active part than their predecessors in the work of the House.

On 6 October 1871 Taiaroa moved in the House "That all Bills or parts of Bills introduced into the House especially affecting Native affairs be translated into the Maori language, and be referred to the Committee on Native Affairs." Responding, Donald McLean said: ${ }^{47}$

the Government would endeavour to get a translation of such Bills and parts of Bills as had special reference to Native affairs. It would be quite impossible to have all Bills translated in time, with the small power at the disposal of the Government to make such translations. In all

\footnotetext{
44 (6 September 1870) 9 NZPD 516.

45 (6 September 1870) 9 NZPD 516.

46 (6 September 1870) 9 NZPD 517.

47 (6 October 1871) 11 NZPD 158.
} 
cases in which Natives were immediately affected, the honourable members for the Maori districts would have full information given. A translated summary of all Bills relating to Native affairs should be prepared.

Gisborne expressed alarm that making a translation of the Native Land Bill would prevent its passage this session and McLeod thought "A condensed statement would make matters clearer than a full translation and would be preferable". Parata said that Taiaroa did not require that the Bills be printed at this stage but only that they be translated: "When the session has concluded the printing can be done." 48 The House divided on the question but the motion was passed 41 to 15 .

On the same day in the Legislative Council Richmond moved ${ }^{49}$

That it be the duty of the Hon. the Speaker to see that all Bills specially affecting the Native race shall be translated and printed in the Maori tongue for the information of Her Majesties subjects of that race, in accordance with rule 316 of the Standing orders, and that the printing shall take place before the Bill is read a second time.

He observed:

that rule no 316 had been one of the Standing Orders for many years, but, as far as he recollected, it had never been in any single instance brought into operation, and his object in bringing forward the motion was that it might no longer remain useless. He thought there could be no better opportunity for bringing it into operation than the present, when the Native Land Court Bill was before the Council.

Sewell indicated that the Government was willing to comply with the motion and it was adopted. Mantell pointed out that: ${ }^{50}$

he had called the attention of the Council to the subject of the Standing Order in question several times and the Council had always gladly agreed to order any Bills to be translated, and to have due effect given to the real attention of the Standing Order which was, that Bills proposed to be introduced might be in the hands of people specially affected before it was likely they would be passed into law. During the present session he had abandoned that practice. He felt to propose that the Native Land Court Bill should be translated into Maori, and circulated for the information of the Natives would really be only to retard the passing of the measure without any possibility of getting a valid expression of opinion from the persons affected, before the Bill should pass into law.

$48 \quad$ (6 October 1871) 11 NZPD 158.

49 (6 October 1871) 11 NZPD 146.

$50 \quad$ (6 October 1871) 11 NZPD 146. 
A further motion from Mantell was adopted by the Council on 10 October: ${ }^{51}$

That, in order that those specially affected thereby should have an opportunity of considering and expressing an opinion upon Government Bills specially affecting the Native race, all such Bills as the Government may propose to introduce in any session should be prepared, translated, printed and circulated at the earliest possible period previous to their introduction.

The insufficiency of the printed Acts is further indicated by Haultain's letter to Donald McLean of 18 July $1871: 52$

I will now detail some minor objections that have been made to other parts of the system, and would first refer to the necessity of instructing the Natives more fully in the various laws that have been made for guarding their rights and interests, and for protecting them from imposition and injustice. For this purpose a mere translation of the Acts in their technical phraseology would be of little assistance; but a summary digest, such as that in respect to Criminal Law by Sir W Martin, should be prepared, and with the Acts, be largely circulated among them.

An example of such a "summary digest" is illustrated as Plate IV. Wiremu Hikairo "an Arawa and assessor of the Native Land Court, and also a clerk in the Chief Judge's Office" stated in a memorandum of 20 April $1871:^{53}$

That the Acts referring to Native Lands should all be translated, he has never seen a translation of the Acts of 1865, though he has been in the Chief Judge's Office for three years. He paid himself for printing at the Bishops press some portions of the Acts, the 75th clause of the Act of 1865, and the 33rd of that of 1867 . The Natives would gladly read the Acts if they could get them; and there are intelligent men amongst them who are well able to explain them to others. If they had been generally circulated, defects might have been found out and remedied before this.

A typical example of such an Act is the translation of the Timber Floating Act of 1873 (see Plate V). Judge Rogan reported that ${ }^{54}$

The [Native Land Court] Act of 1866 has only come to the knowledge of the Natives by hearsay; at least I have not seen a translation. The Native assessors are called upon to assist in

\footnotetext{
51 (10 October 1871) 11 NZPD 183.

52 Colonel Haultain "Return Relative to the Working of the Native Land Courts Acts" [1871] ALJC no 1,6 .

53 "Appendix to Colonel Haultain's Report" [1871] ALJC no 1, 31.

54 "Appendix to Colonel Haultain's Report", above n 53, 42 quoting [1867] AJHR A-10A.
} 
adjudicating under an Act written in a foreign language, which is and must be prejudicial to the satisfactory business of the Court until this is rectified.

On 19 October 1872 the Legislative Council passed another resolution moved by Mantell:

That, in order that Her Majesty's subjects of the Maori race should have a full opportunity of considering such legislation specially affecting them, it is the opinion of this Council that all such Bills as the Government may in any session propose to introduce, should be prepared, translated, printed, and circulated at the earliest possible date prior to their introduction.

In objecting to the motion Waterhouse said: ${ }^{55}$

There had been a great desire expressed that the two races should be assimilated as much as possible, and that they should be placed under the same mode of treatment; and now, while Europeans were not to have Bills distributed amongst them prior to their introduction into Parliament, it was proposed to make a special exception in favour of the members of the Maori race. [. . .] It was the intention of the Government to avail themselves of the advice and assistance of Maori gentlemen in the preparation of various measures connected with that race, which they intended to submit to the consideration of Parliament, and in that way, doubtless, the contemplated action of the Government would be made known to the rest of the Maori race.

\section{KO TE PIRE TUATAHI-THE FIRST BILL IN MAORI}

The first example of a Bill translated into Maori is the Native Councils Bill 1872.56 Introduced by the Native Minister, Donald McLean, the Bill was discussed in the House of Representatives on 22 October 1872. It was intended to allow the settlement of disputes between Maori in selected Native Districts by means of Maori Councils instead of by the English legal courts. The Minister said it would "only be brought into operation in cases where the majority of the Natives in any particular district desired it." Successive members asked McLean to hold the Bill over until the next session, Swanson suggesting that it be circulated among Maori but withdrawn for the time being. McLean assented and withdrew the Bill. ${ }^{57}$

55 (19 October 1872) 13 NZPD 801.

56 Williams, 474 (see Plate VI). In his Bibliography, H W Williams described it erroneously as "the Maori version of the Native Councils Act, 1872".

57 (22 October 1872) 13 NZPD 894-900. This version of the Bill differs in some respects from that published in the Government periodical Te Waka Maori o Niu Tireni vol 8 no 21 (30 October 1872) and may represent a second draft. 
In the next session (on 27 August 1873) Mantell successfully proposed another motion relating to the translation of Bills, in the face of the imminent introduction of a series of major Bills (including the Native Land Bill, Native Reserves Bill, and Native Grantees Bill):58

That in order that this Council may be informed what action, if any, has been taken by the Government in pursuance of the resolution of 19th October, 1872, there be laid upon the table a return showing the titles of all such Bills specially affecting the Maori race as the Government may propose to introduce during the present session, and setting forth the date at which each such Bill was translated, printed and circulated.

His motion was simply to the effect that it was desirable the Council be informed whether the Government had taken any notice whatever of that resolution [of 19 October 1872]. He personally had no information which would justify him in thinking the Government paid any attention to it.

The Colonial Secretary (Dr Pollen) with evident embarrassment: ${ }^{59}$

was sorry to say he very much feared that the answer to the honorable member's motion would be what was called a nil return, but at the same time he was free to admit that such a return ought not to be the answer. It was not a proper answer, and undoubtedly it was both fitting and right that members of the Native race, who were affected by any legislation, should have the means of knowing what was being done in that direction. He had been told that difficulties of a mechanical nature in the Printing Office in relation to printing the Bills had arisen. He hoped his honourable friend's persistency in calling the attention of the Government to the matter deserved to be crowned by some kind of success. He hoped that if the Government were obliged to confess they had not done what they ought to have done in this instance, they would not have to apologise for shortcomings in the future.

58 (27 August 1873) 14 NZPD 637.

$59 \quad$ (27 August 1873) 14 NZPD 637. 
The result of this was that three Bills were found to have been translated. These were the Native Councils Bill 1872, the Native Lands Bill 1872 and the Native Reserves Bill 1872 not all of which survive. ${ }^{60}$

When the Native Reserves Bill 1873 reached a second reading in the Legislative Council on 29 August 1873 a dispute under Standing Order 316 (relating to the printing of Bills in Maori) was raised by Pharazyn, who took the view that since the Standing Order had not been complied with the Council could not proceed to consider the Bill. The Speaker upheld the point of order saying that unless Standing Orders were suspended it would not be in his power to permit the Bill to be proceeded with: ${ }^{61}$

He had already acted on this order and had given instructions to the Interpreter to make the necessary translation. He (Mr Speaker) had been himself in communication with the Government Printer, and had informed him that the Bill would come before the Council today, and asked him to hasten the printing. The Government Printer had now informed him that he could not undertake to print it before tomorrow or Monday. A Translation had been made of the Bill in manuscript for the use of the Native members of the House, and that translation would be under revision by the Interpreter to this Council when he had completed it, it would be placed in the hands of the printers.

Stokes, speaking in the same debate: ${ }^{62}$

thought something more was required than a mere literal compliance with the Standing Orders. The spirit of the Standing Orders was, he apprehended, that laws affecting Natives should be translated in Maori, so that the general effect of a law affecting their interests should be made known to them. If they wanted to satisfy the Natives and make them content with the laws, they should have the Bills circulated in Maori, so that they might have a voice in matters so materially affecting them as this Bill did. They ought at least to be made acquainted with

60 "Bills Affecting the Maori Race" [1873] JLC no 16. McLean's new Native Councils Bill 1872 had been translated and sent to the printer in the middle of July, printed about 20 August and circulated a couple of days later. A copy of this Bill survives but it was never enacted; McLean withdrew it on 20 September (Williams, 474). The Native Lands Bill 1872 was translated and sent to the printer on 15 July and printed "About middle of August". It was circulated in manuscript to the Maori members "as printers hands were full of other work" and was "subsequently amended by the House of Representatives; re-translation made on 4th September; now being printed". This seems to imply two printed versions of the Bill, but neither has survived. The third Bill listed in the return was the Native Reserves Bill 1872 translated and sent to the printer in the first week of August, printed about the middle of August. It was amended in the House and re-translated on 30 August, then reprinted "With amendments, 3rd September" and circulated on 3 September. Here again there appear to be two printing of the Bill, although neither survives.

61 (29 August 1873) 15 NZPD 718.

62 (29 August 1873) 15 NZPD, 719. 
the measures that were to be brought before the assembly, and especially those relating to their lands, about which they were so sensitive.

There are many instances in which Maori members of the House of Representatives (and from 1872 also members of the Legislative Council) pointed out that translations were not available and sought to delay proceedings until they were provided. Wi Tako Ngatata, the first Maori Member of the Council (who was appointed late in 1872) had in his first speech in the Council (15 October 1872) asked that the Wellington College Loan Bill 1872 be delayed "until it had been translated, so that he might understand its purport." 63 Similarly in 1873 he asked the Colonial Secretary not to be in a hurry over the Native Reserves Bill 1873 but "wait until it was translated into Maori, because he wished to understand it thoroughly." 64 On this occasion the Colonial Secretary (Pollen) agreed to consideration of the Bill being postponed and it was discharged, coming up again on 10 September. On the latter occasion Wi Tako Ngatata said: 65

Listen to me. This is my island. It was I who gave it to you. I sold it to you. Therefore why should there be reserves? Why should our rights be brought into this House? For what reason was I invited into this Council? Why was there not a reserve put upon me? Let us have no such provision made for the Maoris. You are teaching us that we are equal to you. You direct us and the Maoris follow your direction. Do not direct that the Maoris shall be treated one way and the Europeans another; that is wrong. Now listen. It is thirty years since the Europeans came here, and there is this difference between the European and the Maori: that it was the European who has a desire to rob the Native. My opinion of this Bill is wrong; I cannot understand it. That is why I asked that it should be printed in the Native language, so that the tribes outside should be able to read it themselves. There are two things I cannot do: I cannot read English, and I cannot understand it, and that is the reason my people have presented you a petition upon the subject of printing Bills in our language. I wish to let you know that I have good desires towards you, as I now live amongst you. We have assisted the Europeans at a time when we were disregarded by our friends; and our property was then robbed from us. We had no disturbances until these laws were introduced; and it now comes to my mind, with reference to the Bill before the Council, that you are now tying us up with a rope, and placing us in the position of horses. You tie the Maoris to a post, and the Commissioners are to come and take care of us. We do not care about this. The laws that are to be made should be good ones, but there are too many weights introduced into this Bill. We cannot bear its weight. You may be able to lift it, but I cannot, and that weighs upon my mind. You are the intelligent

\footnotetext{
63 (15 October 1872) 13 NZPD 651-652.

$64 \quad$ (29 August 1873) 15 NZPD 719.

65 (10 September 1873) 15 NZPD 984.
} 
people and know what is right. You know a great deal about legislation. You say our lands should be taken for the benefit of the natives, and our lands are taken, and our children are to be taught to speak the English language. [. . . When you take the land from under them what is the good of education. Serious thoughts have come into my mind in the last few years. I have not seen any justice done by the Europeans lately. I have been invited to come to this Council to listen to what is going on, when all at once I am met with this heavy burden, which I cannot lift. To you it may be light but I cannot bear it.

\section{$X$ THE WAKA MAORI (1871-1877) AND THE WANANGA (1874-1878)}

The demise of the Maori Messenger ${ }^{66}$ in 1863 and several other shortlived papers printed in Maori left a hiatus to be filled by Te Waka Maori o Ahuriri ${ }^{67}$ from 1863-1871. Donald McLean, for much of that time the de facto editor, became a minister in the Fox Ministry in 1869 and retained his post almost until his death in 1877. Te Waka Maori o Niu Tireni issued 1871-187768 was a Wellington based title, superseding Te Waka Maori o Ahuriri, and changing title on relocation. It remained under the editorial control of Donald McLean's associate James Grindell and became a propaganda mouthpiece for the Native Department during McLean's long tenure of the Native Ministry. Complaints about it appeared as early as 1872 when Stafford complained to Waterhouse that it was being employed for party and political purposes. ${ }^{69}$ On 17 October 1876 the House of Representatives struck out the vote for its publication in the estimates, its patience at last exhausted, in an effort to terminate the paper. The issue of 7 November 1876 announced that the paper would cease but the editor and Minister continued regardless as, according to Whitaker, several gentlemen came forward to guarantee the publication at no cost to the government, among them being the Premier (Atkinson) and the Native Minister himself!

66 Williams, 271, 335.

67 Williams, 367.

68 Williams, 463.

69 See (29 September 1877) 26 NZPD 1-39; (28 September 1877) 26 NZPD 47-85; (1 October 1877 ) 26 NZPD 90-98, 103-118. 
The great rival of Te Waka Maori was Te Wananga $1874-1878 .{ }^{70}$ Te Wananga survived until the end of 1878, but was uneconomic and although a revival was foreshadowed on its suspension, the paper did not resume. Te Waka Maori was revived on 19 December 1876 and continued until 17 July 1877, even using the Royal Arms in the masthead and the Government Printer's imprint, under the fiction that the paper was self-supporting through subscriptions paid by Maori. An issue was printed on 1 August 1877 but was suppressed on the Minister's orders when questions were asked in the House as to whether the publication was being conducted at Government expense. ${ }^{71}$ Shortly thereafter, however, the editor and Government Printer were convicted of libeling Henry Russell in articles published in July and August 1876 . They were fined $£ 500$.

The incident resulted in a motion of no confidence in the Government moved by Larnach. This was debated at length on 27 September through to 2 October but Larnach's motion was eventually lost. ${ }^{72} \mathrm{~A}$ few days later, however, the Government fell on another want of confidence motion. ${ }^{73}$

With the demise of Te Waka Maori as an official paper in July 1877 Te Wananga was left to itself. But on 9 March 1878 Grindell issued a circular stating that the paper would be revived at Gisborne to be "essentially a Maori vessel, navigated and owned to some extent by Maories themselves, and altogether independent of Government influence. ${ }^{74}$ On the date the first issue of the new paper appeared under the title Te Waka Maori o Niu Tirani ${ }^{75}$,

70 Williams, 504. In acknowledging receipt of the first issue of Te Wananga on 7 August 1874 the editor of The Hawkes Bay Times, which had published a column in Maori under the title Nga hua o te mohiotanga ma nga tangata Maori (although unlike its predecessors it had not been issued as a separate title), says:

During a late visit to Auckland Henare [Tomoana] became the purchaser of a press and types, and brought down with him a native printer. Te Wananga was issued on Wednesday, the 5th inst; it is well-printed, on a sheet letter-paper size, occupying three pages; and contains a long and somewhat florid leading article, and a number of news items - the latter being extracted from our own Maori column. The object of Te Wananga is set forth in the introductory article. It will agitate for reform in the laws affecting natives, additional native representation, \&c.

It was printed on the old Columbian press brought to New Zealand in 1842 for Colenso, and now in the Museum of New Zealand, Te Papa Tongarewa.

71 A copy of this issue (vol 13 no 13 dated "18 Hepetema, 1877") is in a set in the Alexander Turnbull Library but no other copies of the issue are known and it seems likely that it was not distributed.

72 (2 October 1877) 26 NZPD 118.

73 (9 October 1877) 26 NZPD 284.

74 This circular was reprinted in Te Waka Maori vol 1 no 2 (4 September 1878).

75 Williams, 554. 
the Native Minister revoked Grindell's licence as an interpreter under the Native Land Act, 1873.

Thus Te Waka Maori survived the demise of Te Wananga, which succumbed to a libel action and lack of support, but it shared the same fate less than a year later. The whole period was marked by vitriolic attacks on Grey and Sheehan, the then Native Minister. The paper survived little more than a year. It was relocated to Napier in July 1879 but at a meeting of shareholders on 6 October: "it was unanimously decided to discontinue the publication of the Waka and place the affairs of the Company in the hands of a liquidator without delay." Inadequate support was held responsible, as the paper had only been sustained by European finance, few Maori being subscribers: ${ }^{76}$

We have made an effort to supply the Maories with a medium for the conveyance of information to them respecting matters and things affecting their interests and for the expression of their interests thereon, but we have not received from them that material support which we think we had a right to expect. Henceforth, if they require a paper they will themselves have to bear the expense of publishing it, they need not expect the Pakehas to do it.

This terminated the publication of politically controversial periodical literature in Maori until 1892 with the appearance of the newspaper of the Kingitanga, Te Paki o Matariki.77

\section{TRANSLATIONS OF BILLS AND ACTS FROM 1873 TO 1877}

At least seven Bills from 1873 were translated and printed in Maori as well as several Acts. The example illustrated in Plate VII is Taiaroa's Maori Representation Acts 1867 and 1872 Amendment Bill of 1873 (see Plate VII). While practices differ from year to year it seems likely from various indications in Hansard that even when Bills were translated into Maori for the benefit of the Maori members, they were not necessarily printed. For example, in reference to the Qualification of Electors Bill 1875 Reynolds remarked that each of the Maori members had a copy of a translation, although the translation had not been printed, and he mistakenly alleged that there was no requirement under Standing Orders for the translation to be printed. ${ }^{78}$ Language featured prominently again in a debate held on 15 September 1875 concerning Maori representation. The Native Minister (McLean) said. $7^{79}$

76 Te Waka Maori o Niu Tirani vol 1 no 42 (25 October 1879).

77 Ca 1892 to ca 1935 . Williams, 810 and $810 \mathrm{~b}$.

78 (28 September 1875) 19 NZPD 35.

79 (15 September 1875) 18 NZPD 347. 
The Native members who had sat in the House had felt the disadvantage of not knowing the English language; they had made use of that argument as a reason for inducing the Native youth of the country to attend the English schools and to acquire a knowledge of the English language. It had been the desire of the Government to carry out this object by establishing schools among the Native people, and by furthering in every possible way anything that might tend to their advantage and civilisation as a race. The Government had no desire whatever to perpetuate any differences that could be avoided. The Special Representation Act would expire in 1877 , by which period he hoped many of the Native youth would be able to come to this House and represent the people, would be able to speak in the English language, and would adopt English customs.

\section{Takamoana responded that ${ }^{80}$}

it would be better to let the Natives go out of the House altogether if their numbers were not increased" and asked that the question of Maori representation be debated openly and not left entirely to the Native Minister: "so that we may be able to ascertain whether we are one people, or, on the contrary, that we may know by what you say that we are two separate people.

Taiaroa took the same view: ${ }^{81}$

He knew from his own experience in the House that they were now here in a false position. I. . .] Therefore it was that he did not care to speak very much in this House. It was not worth while speaking; there was nothing to be gained by the Natives. The best thing for the Maoris was to go out altogether. He intended himself to go out this year. He hoped no member of the island would come forward next Parliament. There was no good to be gained by it.

In reply Sheehan admitted: 82

that under the present administration [of McLean] an earnest attempt had been made to lead the Natives not to talk Maori, but to speak English, and to become English people. He knew that that attempt was very successful; and he would be very glad to see the honorable gentleman asking for more public money this year than last for the purpose. He knew no money that was better spent, or would produce more beneficial results in the future.

Concern was regularly expressed over the way that legislation affecting Maori was delayed until late in a session and then rushed through without being printed in Maori and disseminated, even before the Maori members had an opportunity to digest it and

80 (15 September 1875) 28 NZPD 348.

81 (15 September 1875) 18 NZPD 348-349.

82 (15 September 1875) 18 NZPD 349. 
confer about it. For example on 19 October 1875, following the abolition of the Provinces, Atkinson introduced into the House a Confiscated Lands Bill $1876 .{ }^{83}$ The Maori members appear not to have been present, but despite opposition the Bill was taken through all stages before the House rose at $3.00 \mathrm{a} . \mathrm{m}$. and was then sent to the Council the following day. When Pollen introduced it in the Council Ngatata opposed it along with other members and the Speaker of the Council stated "he had not had an opportunity of having this Bill translated into Maori, as he had received it only half an hour before. It was certainly doing an injustice to the Native members of the Council not to give them an opportunity of reading the Bill in their own language." ${ }^{84}$ The Council postponed the second reading until Friday 22 October, killing it since the Prorogation occurred on Thursday.

The year 1876 saw the end of Donald McLean's control of Native Affairs. On 11 August he introduced the Native Land Sales and Leases Bill 1876 and once again the absence of a copy of the Bill in Maori proved contentious. Sheehan immediately rose to debate the question saying: 85

The Government should make it a sine qua non that Native Bills of an important character should be submitted at an early period of the session, and under such circumstances that they would become known to the Native population. What will happen in respect to this Bill will be similar to what has occurred in previous sessions. The Hon. the Native Minister introduces his Bill at the end of the session when the House is half-full, and when honourable members are anxious to get away. They are passed through all their stages without receiving that careful consideration which measures of that kind ought to have. [. . . The House has over and over again taken steps to protect the Native interests in this House; but those steps have not been effective.

Taiaroa rose to support Sheehan, saying: ${ }^{86}$

It is only right that the Government should circulate Bills of this nature before the commencement of the session. This, in particular, is a Bill which may result in prosperity or the reverse to the Native race; and yet we have not yet had either the Bill itself or a translation of it. I would ask the Government to furnish the translation during the coming week if possible.

He was supported by Takamoana who said: ${ }^{87}$

\footnotetext{
83 (19 October 1875) 19 NZPD 546.

84 (19 October 1875) 19 NZPD 556-557.

85 (11 August 1876) 21 NZPD 257.

86 (11 August 1876) 21 NZPD 258.

87 (11 August 1876) 21 NZPD 258.
} 
I hope the translation of the Bill will be furnished to us at the earliest possible moment, so that not only we, the Maori members of the House, may become acquainted with its contents, but that we may be able to circulate it amongst the Maori people outside, and thus give them an opportunity to make known their opinions in regard to it. [. . . I hope the members of this House will approve of the suggestion that this Bill should be circulated amongst the Maori people. They will do so if they think the Maoris are men; but if they pass the Bill without doing so I shall think they regard the Maoris as dogs.

The former Governor, George Grey, then pointed out Standing Order 355 of the House of Representatives. McLean in reply said: ${ }^{88}$

I was quite aware of the existence of that Standing Order, and I can assure the honourable gentleman that he need be under no apprehension upon the point. It is our intention to print the Bill, and have it circulated. We have every desire to give to the Maoris in all parts of the country every information we can in reference to the Bill, which will be circulated as soon as possible.

The Speaker commented that "as soon as the Bill is placed in the hands of the officers of the House, instructions will be given to have it translated into the Maori language" but Swanson asked what provisions were to be made for circulating it and asked that it be printed and circulated with Te Waka Maori and the anti-government paper Te Wananga. ${ }^{89}$ This was taken up by E G Wakefield who commented 90

you might as well paste it on the underside of the table of this House as publish it in the Waka Maori alone. That Waka Maori is one of the greatest scandals that ever were introduced into the machinery of the government of any country [. . . the Waka Maori is a newspaper devoted to advocating the policy of the Government of the day [. . .] for the political advantage of the Ministry of the day.

Sheehan explained his long-standing suspicions about the conduct of the Native Minister and his Department and reaffirmed that: 91

the demand for publicity in the case of measures affecting the Native people is infinitely stronger than in the case of Europeans. This matter can never reach the native mind fairly unless by publication of the Bill itself in the Native language under the authority of this House; otherwise this Bill will only reach the Native mind through the medium of that highly

\footnotetext{
88 (11 August 1876) 21 NZPD 259.

89 (11 August 1876) 21 NZPD 261.

90 (11 August 1876) 21 NZPD 261-263.

91 (11 August 1876) 21 NZPD 267
} 
respectable paper the Waka Maori - a paper which has over and over again been prostituted to support the Government - a paper paid for out of the public revenue. It has been used for promoting the political views of the Native Minister against those of a large section of this House.

Similarly the debates for the year 1879 contain several discussions of the Standing Orders in relation to Maori texts. In the House of Representatives on 9 August 1879 Tainui had said "I consider the proper course would have been to have had these Bills [the Grey Ministry's Maori Prisoners Trials Bill 1879] translated so that Native Members might have had an opportunity of considering them" 92 and the Speaker had said ${ }^{93}$

As one of the Maori members has expressed regret that these important Bills were not translated into the Maori language, I wish to state that it would have been my duty in compliance with one of the Standing Orders to have had these Bills translated into the Maori language for their use, were it not that the House in the early part of the day suspended all Standing Orders which might impede the passage of these Bills at one sitting.

In the Council on the same day Whitmore moved the suspension of Standing Orders so that the first of these could be taken through its second reading at once. Waterhouse objected: ${ }^{94}$

that, under the Standing Orders, it is imperative that all Bills affecting the Maori portion of the population should be printed in Maori prior to being read a second time. I do not know whether, the Standing Orders being suspended, that regulation is imperatively necessary at the present time; but it appears to me that, if it be not imperative that this Bill and the Peace Preservation Bill should first of all be translated into Maori, it is imperative as a simple matter of justice, that we should have some knowledge that the Bills are thoroughly understood by the Maori Representatives in this branch of the Legislature. We ought not to suspend the Standing orders on such an important point as this unless we have an assurance that the Maori representatives in this branch of the legislature have such a knowledge of the contents of these Bills that they are prepared to waive insistence on the Standing order.

Whitmore said that ${ }^{95}$

the question has already been decided in another branch of the legislature, or we should not see these Bills here - I hope the Council will overrule the objection which has been taken,

92 (9 August 1879) 31 NZPD 552.

93 (9 August 1879) 31 NZPD 560.

94 (9 August 1879) 31 NZPD 538.

95 (9 August 1879) 31 NZPD 538. 
even though in ordinary cases it rigorously insists upon having Bills affecting the Maori race carefully printed and circulated among that portion of the population.

But Taiaroa replied: ${ }^{96}$

I wish to say that the motion for the second reading is not in accordance with the Standing Orders of this Council because the Bills have not been translated into Maori and circulated. Therefore the Maoris do not understand the purport of them; and, if they were agreed to by us now, afterwards it might be said that the Native members did not object to them at the time when they were brought into the Council. Therefore I should like to move that these Bills be left over until next session, owing to their not having been circulated and translated in accordance with the Standing Orders of this Council.

Pollen supported Taiaroa but Whitmore's motion was supported by Buckley and Robinson, the latter saying "We have only just had the Bills sent up. The Maoris have an interpreter; and I fancy they will be able to comprehend the Bill from the interpreter, and will be just as intimately acquainted with it as the European members of the House." Grace suggested that the Maori members of the Council did understand the Bill and were merely using the Standing Order as a pretext to hold it up, and Waterhouse accepted this view, withdrawing his earlier opposition to the suspension of Standing Orders. The Speaker commented that something more had to be done and observed that the Standing Order was drawn very loosely. He quoted Standing Order 318 and added: ${ }^{97}$

That is a prospective direction; and, if I were confined in my interpretation of that to the four corners of the rule, I should say that the objection taken to proceeding with this Bill would fall to the ground, inasmuch as it would be my duty to see that these Bills are translated at some future time. But I have instituted inquiries and have ascertained that the practice has been this: that Bills affecting the Maoris have frequently been suspended in their procedure until they have been translated. It would not become me to deviate from this practice, and therefore it is clearly my duty to put this additional question ; and, if it is decided in the affirmative, then all barriers to proceeding will be removed, but the Council will do it with their eyes open.

Whitmore then asked ${ }^{98}$

Is it not a proof that it has never been absolutely considered to be the rule, that upon no occasion have Standing Orders been suspended, except on the special motion of some honourable gentleman, until Bills affecting the Natives were translated into Maori? The practice has been for some honourable gentleman to move that the Bill be adjourned until it

\footnotetext{
96 (9 August 1879) 31 NZPD 538.

97 (9 August 1879) 31 NZPD 540.

98 (9 August 1879) 31 NZPD 540.
} 
has been printed and circulated among the Maori members. I believe it is a fact that Bills in which they take a great interest have usually, out of courtesy to the Maori members, been so adjourned; [. . . ]" but Bell then dismissed the whole argument by saying: "I think the question of the interpretation of Standing Orders is wholly immaterial [. . . I do not think the Natives interested would care a bit about the Standing Order, and I do not think there is any objection to that Standing Order being suspended.

The suspension of Standing Order 318 was then put and carried on the motion "That the Standing Order No 318 be suspended, so far as to enable the two Bills - viz the Maori Prisoners Trials Bill, and the Peace Preservation Bill, to be proceeded with, prior to their being translated into the Maori language." While this implied an assumption of the future translation of the Bills, this translation was never carried out. The Maori Prisoners Trials Bill passed through all stages forthwith, but the Peace Preservation Bill was killed at the second reading stage. The Maori Prisoners Trials Act 1879, the purpose of which was to allow the Governor to fix a date for the trial of Te Whiti and others by Order in Council (in effect allowing three months detention without trial) was not translated into Maori.

\section{COMPENDIA OF SEPARATELY PRINTED BILLS AND ACTS 1878 TO 1883}

Up until 1878 the survival of printed Bills was a haphazard affair, most of those which have survived being represented by single copies retrieved from collections of political papers ${ }^{99}$ or gathered subsequently into collections and bound together for the General Assembly. Even the set of Bills in the Parliamentary Library and the set held in the Office of the Parliamentary Counsel are incomplete. With a few exceptions these sets of Bills do not contain Bills in Maori.

On 26 November 1878 in the Legislative Council "On the motion of Mr Taiaroa it was ordered that all Bills which have been translated into the Maori language during each session, be bound in a similar manner to the general Statutes, and that they be placed in the General Assembly Library as a means of reference for the Maori members." 100 The untitled 1879 volume ${ }^{101}$ contains the Confiscated Lands Inquiry and Maori Prisoners Trials Act

99 For example, those of Donald McLean and of Walter Mantell.

100 No such collection survives in the Parliamentary Library but two such collections acquired with other papers from the old Maori Affairs Department Library are in the Alexander Turnbull Library.

101 Now located at Alexander Turnbull Library Printed Collections Pq499M 1879 NZ PAR Acc. 254891. 
$1879^{102}$ followed by eleven printed Bills ${ }^{103}$ with a manuscript list of contents on the inside front cover. The practice introduced in 1879 was followed in 1880, and a matching volume for that year ${ }^{104}$ contains fifteen Bills ${ }^{105}$ along with four Acts, ${ }^{106}$ again with a manuscript list of contents on the inside front cover. These were probably compiled for officials of the Native Department or the translators, and were not seen by $\mathrm{H} \mathrm{W}$ Williams when he compiled his Bibliography (1924) and Supplement (1928).

About this time the practice developed of printing only the clauses of the Act which were of specifically Maori interest. An example, illustrated as Plate VIII, is some extracts from the Sheep Act of 1879 (misdated as 1878 in its title). For 1881 the procedure was changed as the Alexander Turnbull Library holds a compendium with a printed title page and contents list, followed by a compilation of eight Acts and seven Bills. This has the title Nga Ture o Niu Tireni: $i$ pahitia $i$ roto $i$ te tau wha te kau ma rima o te Kuinitanga o Kuini Wikitoria, me te nohoanga tuatorutanga o te Paremete tuawhitu o Niu Tireni, i noho ki Poneke $i$ timata $i$ te rua te kau ma waru o nga ra o Mei, 1881 (The laws of New Zealand passed in the forty-fifth year of the reign of Queen Victoria and the third session of the seventh Parliament of New Zealand held at Port Nicholson begun the 28th May 1881). Each Bill or Act in the compilation appears as a Maori text followed by the English text, all the items being separately paginated. ${ }^{107}$

This work was probably never published but may have had a limited circulation in official circles. It contains eight of the nine Acts known to have been printed in Maori -

102 Williams, 563.

103 Williams, 563a: the Native Lawsuits Bill, Maori Representation Bill (Plate IX), Native Reserves Vesting Bill, Qualification of Electors Bill (Plate X), Fencing Bill, Onewhero Grant Empowering Bill, Murihuku Native Reserves Grants Bill, Confiscated Land Enquiry and Maori Prisoners Trials Bill, Maori Representation Act 1867 Amendment Bill, and Elective Council Bill (all to be described in EMI).

104 Now located at Alexander Turnbull Library Printed Collections "Pq499M 1880 NZ PAR Acc 258268".

105 None of these were described by Williams, but each will be described in EMI. They are the Taonui - Ahuaturanga Land Bill, Native Land Court Bill, Native Land Acts Repeal Bill, Native Land Sales Bill, Fencing Bill, Native Land Frauds Prevention Bill, Native Lawsuits Bill, Native Succession Bill, Maori Prisoners Bill, Maori Prisoners Detention Bill, Native Reserves Bill, Native Lands Stamps Duties Bill, Native Lands Contract Act Validation Bill, (Waikato) Confiscated Lands Bill, and Native Schools Sites Bill.

106 Native School Sites Act, Dog Registration Act, Brands and Branding Act and Waikato Confiscated Lands Act. See Williams 582, 583, 584 and 587 respectively.

107 Bagnall, 4115 (not in Williams, included in EMI). It seems probable that the title page was printed for the particular copy, which belonged to George H Davies and is inscribed "G H Davies Native Office 1881." 
the Dog Registration Act Amendment Act is not included ${ }^{108}$ but is known from another source - together with the texts of the Bills "affecting natives" which were not passed during the session ("Nga Pire kahore enei i pahitia"). It does not include the Maori texts of those Bills which were enacted and so appear in their final form as printed Acts. ${ }^{109}$ It is probable that a similar practice was followed the following year, as another unique volume with a printed title page and containing Acts and Bills for 1882 has been identified in the Parliamentary Library, entitled Ingoa o nga Ture me nga Pire, Tau 1882. Nga Pire. Kaore enei $i$ pahitia. (Names of the Acts and Bills, year 1882 - The Bills not passed). ${ }^{110}$ A few separate copies of some of these Acts have been located, but none of the Bills survive as separate copies. The fact that only one copy of the collection has been seen suggests that it is a unicum with printed cover and contents made up especially for the Parliamentary Library. This copy, probably produced under the same circumstances as that of the previous year, has not previously been documented. ${ }^{111}$

Regularity was established by the annual collections of Acts affecting native lands, Etc., (in English and Maori) passed by the General Assembly, Session [date] which began in

108 Williams, 607.

109 For details of these items see entries in EMI. This collection of Acts and Bills (Bagnall, 4115; not in Williams) is only doubtfully "published" but includes the Crown and Native Lands Rating Bill, Alienation of Native Land Bill, Murihiku Native Reserve Grants Bill, Native Reserves Bill, Waipawa Land Dispute Bill, Native Committees Empowering Bill, Native Land Act Amendment Act 1873 Amendment Bill, (but not the Thermal Springs Districts Bill, Native Land Division Bill, West Coast Settlements Reserves Bill). The Acts included in the collection are the West Coast Settlement Reserves Act (Williams, 606), Thermal Springs District Act (Williams, 612), Native Land Acts Amendment Act (Williams, 611), Licensing Act (extracts only, Williams, 610), Native Succession Act (Williams, 604), Native Lands Frauds Prevention Act (Williams, 605), Fencing Act (Williams, 608), Dog Registration Act Amendment Act (Williams, 607), and Rabbit Nuisance Act (Williams, 609).

110 This contains Maori texts of the Amnesty Act, Crown and Native Lands Rating Act, Indemnity Act, Licensing Act Amendment Act, Orakei Native Reserve Act, Native Land Acts Amendment Act, Native Land Division Act, Native Reserves Act, clauses of the Public Works Act, Rabbit Nuisance Act, Waikato Confiscated Lands Act, West Coast Peace Preservation Act, RangipoMurimotu Agreement Validation Act and Te Aroha Township Act. One Act is known in a Maori version which is not included in the collection: the Dog Registration Act 1882. The volume also contains Maori texts for several Bills which were not passed: Greymouth Native Reserves Bill, Maori Representation Bill, Maori Representation Act 1867 Amendment Bill, Mohaka and Waikare Native Claims Settlement Bill, Murihiku Native Reserves Grants Bill, Native Committees Empowering Bill and Native Land Court Act 1880 Amendment Bill.

111 Ingoa o nga Ture me nga Pire. Tau 1882, to be described in EMI; not in Williams, not in Bagnall. 
1889. ${ }^{112}$ No collection had been issued for 1883 although separate Bills and Acts exist in some cases. ${ }^{113} \mathrm{H} \mathrm{W}$ Williams lists many of these Bills and Acts but his schedule is incomplete and was not always based on the examination of an actual copy. ${ }^{114}$

The reasons for these discrepancies become clear from H W Williams' own statements about the way he compiled it. For example one of the numerous spurious items cited (Williams: 452 "no copy seen") is evidently based on a citation of the Native Lands Act Amendment Act 1870 giving the title in translation as "Te Ture whakatikatika i nga Ture Whenua Maori, 1870." The comparable English text of the Act consists of only three clauses, repealing one section of the principal Act (the Native Lands Act 1865) and extending the time within which re-hearings of claims under that Act might be heard to six months. It seems unlikely that a Maori translation of this technical Act was ever produced. Another spurious item (a supposed translation of the Land Transfer Act 1870) is cited twice by $\mathrm{H} \mathrm{W}$ Williams ${ }^{115}$ under two different Maori titles with the remark "This [ie 454] and the following entry are from references in other Maori translations of Acts, and illustrate the carelessness with which Acts were sometimes rendered into Maori." The Land Transfer Act 1870 is a major piece of legislation, consisting of 148 clauses, but nothing in it specifically relates to Maori land. It seems unlikely therefore that it was ever translated into Maori.

Williams interpreted references to Acts (and to their repealing Acts) in subsequent years as if they referred to actual publications. Many of these Acts do not seem to have ever been printed in Maori. Moreover Williams did not examine the series of printed Bills

112 See for example Acts affecting Native Lands, etc., (in English and Maori) passed by the General Assembly, session 1889 (not in Williams, not in Bagnall, to be described in EMI). The series appears to have ceased with the compilation for 1910 (printed 1911) which contains fifteen acts printed in Maori only and with the variant title Acts affecting Native Lands Etc (in Maori), passed by the General Assembly, Session 1910.

113 These will be described in EMI. Only one of the nine Bills in Maori for 1883 has been located and this is the Native Land Laws Amendment Bill 1883. The bills which are referred to in debates but which are not extant are the Native Land Acts Amendment Bill No 1, Native Committees Bill, Middle Island Native Village Control and Regulation Bill, Maori Representation Act 1867 Amendment Bill, Middle Island Half-Caste Grants Bill, Taumutu Native Commonage Bill, Murihiku Native Reserves Grants Bill, and the Thermal Springs District Act 1881 Amendment Bill. It is probable that all were printed. For the Acts printed in Maori in 1883 see Williams 651662; these will all be described in more detail in EMI.

114 For example in Williams, 637 the Native Land Division Act, 1882 is described as "Ture Wehewehe Whenua Maori, 1882. $340 \times 218$. [mm] Pp. 4. Government publication, 1882. Translation of the Native Land Division Act, 1882." with the title taken from the short title of the Act and a misrepresentation of the size (actually $350 \times 220 \mathrm{~mm}$ ). 
and of "Bills Rejected" (also called "Bills Thrown Out") in the Parliamentary Library and the Clerk's Office. These sets contain numerous Bills in Maori omitted from his Bibliography of Printed Maori to 1900.116 Brief notes on significant developments in the legislative history of Bills and Acts in Maori are provided here.

\section{ACTS AFFECTING THE NATIVE RACE, 1866 TO 1882}

Although no fewer than eighty-five Acts were passed in the 1866 session of Parliament (all being published together as a supplement to the New Zealand Gazette of 17 August 1866), no Maori translations of any of these were issued, even of those "affecting Natives". Nor do translations of Acts for this year appear in the Kahiti o Niu Tireni established in August 1865. These translations of Acts first appeared in 1867.

The Kahiti or Maori Gazette, as it was known, was the official government medium for communication with Maori from 1865 and included all public notices which were required to be notified to Maori. It had been an initiative of J E Fitzgerald when Native Minister. ${ }^{117}$

As pointed out above, there are many discrepancies in $\mathrm{H} \mathrm{W}$ Williams' listing of Acts as well as Bills. For example he lists Te Ture Mahi Tio 1866 (the Oyster Fisheries Act 1866) on the basis that "later amendments were translated into Maori". ${ }^{118}$ But he had not seen the principal Act in Maori and there is no evidence that such a Maori text ever existed. Similarly the amending Act of 1869 listed by Williams probably did not exist. ${ }^{119}$

The parliamentary session of 1867 ( 9 July to 10 October) passed ninety-five Acts, of which a number could be termed "Acts affecting Natives". Williams lists three of these but one is a duplicate listing, so there should be just two. ${ }^{120}$ Neither of these has been seen,

116 These printings of Bills and Acts are to described in EMI.

117 Kahiti o Niu Tireni 1865-1930 (Williams, 407). The original purpose of the publication is indicated by the preface signed by Fitzgerald and his successor Colonel Russell, which appeared in issues for the first year. Over time Te Kahiti came to include not only proclamations and speeches from the throne by the Governor on the opening of sessions of Parliament, but also Land Court business, Orders in Council, Proclamations, Native Department notices and advertisements and explanations of statutes and regulations. Within a few years it was mainly composed of Native Land Court notices. It continued until the end of 1930.

118 Williams, 418.

119 Judge Rogan's report on the workings of the Native Lands Act 1865 also indicated that "The [Native Lands] Act of 1866 has only come to the knowledge of the Natives by hearsay; at least I have not seen a translation." "Report of Mr Rogan as to the Working of "The Native Lands Act $1865^{\prime}$, in the District of Kaipara" [1867] AJHR A 10A 4.

120 His items 428 and 430 are the same, being a supposed Maori translation of the Maori Real Estate Management Act 1867. His 429 is a supposed Maori translation of the Auckland and Onehunga Native Hostelries Act 1867. 
however, and there is no evidence that either existed; neither is listed in the Legislative Council return of all Acts printed in Maori up to the year 1868. Williams, following his common practice, inferred their existence from translations of the short titles to which reference was made in subsequent amending legislation. The one Act of 1867 which was printed in Maori and seen by Williams was the Native Schools Act $1867 .{ }^{121}$ He overlooked the Maori Representation Act 1867.122

The only purported Maori translations of Acts for 1868 are the Trigonometrical Stations and Survey Marks Act $1868^{123}$ and a supposed translation ("no copy seen") of the Native Lands Act Amendment Act 1868. ${ }^{124}$ The latter Act is a short technical one affecting the duty payable on leases "on which the annual rent does not exceed $£ 10$." It is unlikely that this was translated into Maori. ${ }^{125}$

121 Williams, 342b.

122 Maori Representation Act 1867 with the short title "Ture whakatu tangata ki roto ki te Runanga Nui hei Kai whakarite mo te Iwi Maori, 1867" (not in Williams) located in the papers of the Resident Magistrate at Wanganui, Richard Woon, in Archives New Zealand, MA-WANG series 4 no 9 . Another copy is found in a bound set of the Kahiti in the Parliamentary Library.

123 Williams, 437.

124 Williams, 438.

125 In evaluating these citations for EMI I considered this listing and scores of others as entirely spurious. Those which did exist are described in Early Maori Imprints.

For similar examples of spurious translations see Williams items 443,444 and 445 , all allegedly printed in 1869; an account of these will be found in the comparative concordance to EMI. Two Maori translations of Acts (Williams, 456 and 453) can be confirmed but the other two are spurious. No Acts printed in Maori are known for 1871 but there is evidence that the Native District Roads Boards Act 1871 was translated: in reporting to the Minister (McLean) on 22 December Marsden Clarke says he was "[...] called upon to explain [the Act to a hui at Ohaeawai] for although they had a translation of the Act, it was most incomprehensible to them". (See AJHR 1871 F-4.) For the following year there is only one Act in Maori (Hawkes Bay Native Lands Alienation Commission Act 1872, not in Williams) and only one Bill printed in Maori this being the Native Councils Bill 1872 (Williams, 474) this being the first bill printed in Maori (and rejected). Two Acts in Maori were printed in 1873 and recorded by Williams, but three other Acts he listed are all spurious; he was unaware of ten Bills in Maori which have survived, and these are described in EMI. Similarly in $\mathbf{1 8 7 4}$ he lists three Acts but only one actually exists, while five others were overlooked. There are also two unrecorded Bills in Maori. Neither Bills nor Acts in Maori for 1875 have been recorded. Ten Bills have been identified for 1876 (including one which no copy has survived) and one Act, but none of these were recorded by Williams. For 1877 Williams recorded eight separate Acts, but he had seen only one of them (Williams, 529). The others (Williams, 530-536) are all spurious. Eleven Bills and one further Act not identified by Williams are described in EMI. Williams records three Acts for 1878 but only one was seen (Williams, 549) and the other two appear to be spurious. One further Act (unrecorded by Williams) has been located (Native Licensing Act 1878). 


\section{AVAILABILITY OF BILLS IN MAORI, 1883-1887}

Further problems over the availability of Bills in Maori were experienced in 1883 in debate concerning one of the abandoned bills of 1882, the Native Reserves Amendment Bill 1883. ${ }^{126}$ Grey asked how long the Bill had been translated and circulated in Maori and was told by the interpreter that it had only been circulated in Maori that very morning. The Speaker said he understood that the Bill had been circulated in Maori among the Native members some days before, with the exception of the new clauses which had been given to them in manuscript but not printed: "He thought that all they had to do was to see that the Maori members, who represented the Maori people, got the Bills affecting their race." Subsequently the Speaker said the Clerk informed him that: ${ }^{127}$

the Bill of last session which dealt with this subject was circulated in the Maori tongue among the Maori members some days ago, and that there had not been time to get the new clauses printed, but they were placed in manuscript in the hands of the Maori members, who expressed themselves satisfied with getting those clauses in manuscript; and further that the Interpreter informed them that the Bill was coming on for second reading that evening.

This was denied by Tawhai, the only Maori member then present. ${ }^{128}$ After a long debate an attempt to adjourn the debate was made but the division was lost and the Bill was read a second time at about $3.00 \mathrm{am}$. Taiaroa spoke on the committal of the Bill on 29 August and gave it qualified support. ${ }^{129}$ It was subsequently enacted as the South Island Native Reserves Act 1883 and was then printed in Maori. ${ }^{130}$ Several other translations of Bills introduced that year probably existed but none of these have survived. Of the Acts passed in that year, however, twelve were printed in Maori and issued separately ${ }^{131}$,

126 Which was in fact a revival of the Greymouth Native Reserves Bill 1882, with some new clauses added. The Bill had been introduced on 14 August and the second reading took place on 27 August, but at this time Taiaroa (the most directly involved member) was absent through illness.

(27 August 1885) 46 NZPD 286.

(27 August 1885) 46 NZPD 288.

130 Williams, 654.

131 Williams, 651-662. 
although no printed compilation of them has been found. ${ }^{132}$ The Native Land Disposition Bill 1885 of Ballance ${ }^{133}$ was printed in Maori and widely circulated, from evidence in NZPD, although only one copy has survived and that is incomplete. It appears to be the only Bill printed in Maori for that year. Five Acts were printed in Maori ${ }^{134}$ but there is no indication that any corresponding Bills in Maori appeared.

The Native Land Court Bill $1886^{135}$ was probably available in Maori during the recess and was reprinted in Maori after enactment. The Native Equitable Owners Bill $1886^{136}$ was definitely translated into Maori, according to the Journals of the Legislative Council, as was the Native Reserves Titles Grant Empowering Bill $1886^{137}$ although none of these Maori texts survive and $\mathrm{H} \mathrm{W}$ Williams did not record them. The Native Land Administration Bill, $1886^{138}$ was certainly printed in Maori and circulated, but has not survived. All of these were reprinted in Maori upon enactment and issued separately. ${ }^{139}$ Four Acts ${ }^{140}$ were reprinted and issued as a pamphlet under the title Ture Whenua Maori. ${ }^{141}$

Single copies of the Maori translations of the Native Land Administration Act 1886 Amendment Bill 1887 and the Tongariro National Park Bill 1887 in Maori have survived, although these Bills from the first 1887 session were not enacted. This provides evidence that such Bills were produced even though they are not referred to in Hansard. On the

132 Similarly, in 1884 six separate Acts (Williams, 678-683) were printed in Maori but no printed cumulation is known, and certainly some Bills were printed in Maori, as shown by mention in the debates, but none of the Bills in Maori have survived (Maori Representation Act 1867 Amendment Bill; Native Lands Acts, Native Lands Frauds Prevention Act and the Stamp Duties Act 1882 Amendment Bill; Native Lands Act Amendment Bill; South Island Native Reserves Act 1883 Amendment Bill; South Island Native Reserves Act 1883 Amendment (No 2) Bill; Native Land Settlement Bill).

133 To be described in EMI, not in Williams.

134 Williams, 702-705 and 707a.

135 The Native Land Court Bill 1886 (a revival of the Native Land Court Consolidation Bill introduced late in the previous session).

136 Not in Williams but described in EMI.

137 Not in Williams but described in EMI.

138 An amended version of the Native Land Disposition Bill of the previous year.

139 Williams, 714-717. Clause 5 (only) of the Stamp Act 1886 was issued in Maori also (Williams, 719).

140 The Native Land Administration Act 1886; Native Land Court Act 1886; Native Equitable Owners Act 1886 and Native Reserves Titles Grants Empowering Act 1886.

141 Williams, 718. While many copies of this pamphlet were destroyed in the Government Printer's fire in 1890, it was still being offered for sale in 1892 . 
other hand a third Bill from this year (the South Island Native Reserves Bill 1887) is known to have been translated into Maori on 8 June. ${ }^{142}$ The only copies of these Bills to have survived are in the Bill Book set of the Clerk of the House. ${ }^{143}$

No Bills in Maori survive of the several Bills introduced by Maori members in the second session nor of the various land Bills introduced by Whitaker during December 1887. Nevertheless it seems likely that such Bills existed. Two Acts for 1887 were printed in Maori and have survived. ${ }^{144}$ Although there had been a compendium of Native Land Acts for $1886^{145}$ and there was to be another for eight Acts passed in $1888^{146}$, there was no compendium for 1887 .

\section{TROUBLE WITH NEOLOGISMS, OR LEGISLATTVE "MAORISH", 1886-1888}

On 20 July 1886 Mantell raised in the Council a debate on the "Maori form of legal terms" in which he referred to the Standing Orders requiring the printing of Bills in Maori. He moved: ${ }^{147}$

That the Government cause to be prepared, laid upon the table and printed a vocabulary of such English and legal words and terms, in Maori form as are now commonly inserted in official translations with the words and terms which they are intended to represent; such vocabulary to be arranged (a) with the Maori preceding the English (b) with the English preceding the Maori and (c) the Maori neologisms with the full explanation of their intended meaning in pure Maori.

and in explanation he said:

Now it occurred to him the other day, when some Bills materially affecting Her Majesty's subjects of the Maori race were before the Council, to glance into the translation made for the information of Maori members, in order to see whether it conveyed a true idea of the terms of the Bill. He was perfectly astonished at what he saw, some of the words being quite strange to him, and he was brought up standing at the words tenata kamana and hea, which he had never before seen in Maori and which he knew were not English. On referring to a skilled

142 (8 June 1887) 57 NZPD 830.

143 Now in the Parliamentary Counsel Office, which is otherwise sparsely provided with Maori versions of Bills.

144 Williams, 740 and 741.

145 Williams, 718.

146 Williams 759a; Bagnall, 4102.

147 (20 July 1886) 56 NZPD 1. 
Maori scholar he was told that tenata kamana meant "tenants in common" and that hea meant "share". He thought it was essential that these new words should be duly authenticated. He could give a few more instances of the kind; but any honourable gentleman who was acquainted with the Native language - and he was only slightly so - need only go through the Kahiti or Native Gazette and in almost every line he would meet some word which was neither Maori nor English. [. . . ] With respect to tenata kamana meaning tenants in common he asked the Maori scholar in question what "joint tenants" was in Maori and he was informed that it was tioti tenata. It was for these reasons that he moved the motion standing in his name. He ought to have added that he wished that the list to be compiled should be printed and circulated in the Kahiti.

Criticising the motion Wilson said it would incur a scandalous waste of money and Mantell should pay for it himself, besides which the Maoris never read these books which were compiled for their use. Colonel Brett said that "the aim of honourable members should be to combine the two races together as much as possible; and that would never be done until the Maori language was abolished." ${ }^{48}$ Pollen however thought it could be done in a reasonable time and would be exceedingly useful. Mantell, in reply, said he thought it could be done in a week: $:^{149}$

Either some such course as he recommended in this motion should be followed or they had better repeal the Standing Orders to which he had referred, because it would be wrong to allow a translator in future to substitute tenata kamana for "tenants in common"[ . .] for, so long as the Maoris could be induced to accept the gibberish he had pointed out so long would [the legal] fraternity be able to prey upon their ignorance.

On 1 June 1887 Mantell asked the Colonial Secretary if the vocabulary of Maori neologisms had been prepared and if so when it would be laid on the table. Buckley replied that "it had been found almost impossible to obtain the desired information, while the expense of preparing such a vocabulary would be something enormous; therefore in the interests of the colony, the Government considered it undesirable to do so."150 Mantell returned to the fray the following day with a further motion "That until the vocabulary explaining in Maori the meaning of newly coined words has, in conformity with the order of this Council of 20th July last, been prepared and circulated, the use of such words shall be permitted in papers and Bills translated in obedience to Standing Order 318." He observed that: ${ }^{151}$

\footnotetext{
148 (20 July 1886) 56 NZPD 2.

149 (20 July 1886) 56 NZPD 2.

150 (1 June 1887) 57 NZPD 583.

151 (1 June 1887) 57 NZPD 656.
} 
if they had Bills translated in that way [ie full of neologisms] they did not fulfil the intention of the Standing Order. It had been his intention to move this resolution in the direct opposite to the form in which it now appeared in the Order Paper, as owing to an error of his own, he had accidentally omitted the word "not" after "shall be". He however, preferred now to accept the consequences of his error, as being more conducive to the easy transaction of public business if they sanctioned use of these unintelligible expressions for one session longer rather than stop Bills on account of their not being translated absolutely in accordance with the Standing Orders. [...] As an instance of the extent to which this practice was carried, he went yesterday through the translation of the Orakei Native Reserves Bill and he marked the neologisms. There were over eighty in this small Bill of some two pages.

The following year, on 20 June, Mantell moved in Council ${ }^{152}$

That it be an instruction to the Native Affairs Committee to inquire into and report upon the difficulties which have been alleged to exist in the way of compliance with the order of this Council (20th June, 1886), that a vocabulary should be prepared explaining, in a manner intelligible to the Maori race, the legal and other terms used of late years in translations of Bills into their language, in assumed compliance with Standing Order no 65.

The Committee reported on 28 August ${ }^{153}$

that in obedience to the Order in Council of the 20th June 1888, in reference to the preparation of a legal vocabulary in the Maori language, your Committee recommend that the task of compiling the explanatory legal vocabulary be referred to the permanent Law Officers of the Crown and the Interpreters of the two Houses of the General Assembly.

Nothing further appears to have been done.

\section{COMPENDIA OF ACTS AND BILLS FROM 1888 TO 1900}

No printed Bills in Maori survive from 1888 although some certainly existed and others probably existed. ${ }^{154}$ Eight Acts in Maori are known for this year ${ }^{155}$ as well as a compendium of the eight Acts under the title Native Land Acts (in English and Maori) passed

152 (20 June 1888) 61 NZPD 190.

153 [1888] JLC 210.

154 Maoris Relief Bill; Native Land Court Act 1886, and s 20 of the Native Land Administration Act 1886 Repeal Bill; Westland and Nelson Native Reserves Act 1887 Amendment Bill; Native Lands Bill; Native Land Frauds Prevention Bill; Native Land Court Act 1886 Amendment Bill; Maori Real Estate Management Bill; Middle Island Half-caste Grants Bill; Native Contracts and Promises Bill, and the Crown and Native Lands Rating Acts Repeal Bill.

Williams, 752-759. 
by the General Assembly, session $1888 .{ }^{156}$ This compendium was advertised in the Kahiti on 30 October 1888 , the circumstances indicating that there was no corresponding publication for 1887. No Bills in Maori for 1889 have been found, nor is there evidence for their existence in Hansard. A compendium of Acts in Maori was issued however, Acts affecting native lands etc (in English and Maori) passed by the General Assembly, session 1889. ${ }^{157}$

$\mathrm{H} \mathrm{W}$ Williams recorded five Acts printed in Maori for $1890^{158}$ as well as a volume of Acts Affecting Native Lands, which is a compendium of the five with a special title page). ${ }^{159}$ Several Bills in Maori for this year have been identified in the Bill Books at the Parliamentary Library ${ }^{160}$ although Taiwhanga's Native Land Administration Bill, 1890 has not been located. The existence of these Bills and of comment in the Hansard on the nonavailability of Bills show that some notice was still being taken of the Standing Order. ${ }^{161}$ When the Dog Registration Act 1880 Amendment Bill 1890 was being considered on 26 June, however, and Taipua asked for a postponement on the basis that it had not been translated the Speaker said that the Bill was not one "specially aimed at the Natives."162

On 30 July 1891 Parata asked: ${ }^{163}$

Whether [the Government] will, out of the $£ 7,000$ set apart annually under the Civil List for Native purposes, devote a sum of not less than $£ 100$ per annum for the purpose of translating and circulating among the Natives all Acts, parliamentary papers \&c especially affecting the Maori race? The Natives laboured under a great disadvantage in not knowing what laws were passed with reference to themselves. The Europeans were well acquainted with the laws

156 Williams, 759a. (See Plate XI.)

157 Williams does not record this compendium, but lists its component Acts as if they were separate publications (his numbers 769-771, 771a-771g). This is probably the result of a defective description as the work is paginated continuously and there is no evidence that the Maori versions of the Acts were issued separately. It is clear that the English versions of the Acts were printed specially for the volume.

158 Williams, 784-789.

159 Williams, 789. When the compendium was advertised in the Kahiti in October 1892, the Native Land Court Acts Amendment Act 1891 was included, but this is printed on different paper, with a different Royal Arms and is clearly dated 1891, so is probably a later addition.

160 West Coast Settlement Reserves Acts Amendment Bill; Cattle Bill; Mining Bill (extracts only); Native Land Administration Bill; Native School Sites Act Extension Bill; Horomona Paatu Land Grant Bill; and Native Land Laws Amendment Bill.

161 For example Parata (Southern Maori) on 25 August 1890 observed that no translation of the Native Schools Sites Act Extension Bill was available (25 August 1890) 69 NZPD 229.

162 (26 June 1890) 68 NZPD 7-8.

163 (30 July 1891) 72 NZPD 618. 
passed by the House. Sometimes the first intimation the Natives had of a law being passed affecting themselves was by a sidewind.

The Native Minister (Cadman) in reply said that there were three interpreters employed for the purpose of translating referred to ${ }^{164}$

so that the only point to be considered was that of printing, and he had to say that if the honourable gentleman or any of the honourable gentleman's colleagues would bring under his notice any papers they required to be printed and circulated he should be happy to give every facility for having the work done.

In his second reading speech on the Native Land Bill, 1891 (25 August 1891) the Minister said: 165

The Bill was translated into Maori and circulated within twenty-four hours after the English version was published. Copies of the Bill, both in English and in Maori were forwarded to the principal Post Offices in the North Island immediately after it was circulated. That is a thing unprecedented in connection with Native Bills.

This is yet another illustration of the failure of standing orders.

Only one Act passed in 1891 has been found in a Maori translation, this being the Native Land Court Amendment Act 1891, a short Act of only three clauses. ${ }^{166}$

No Bills in Maori for 1892 have been seen, although a large number of Acts in Maori were printed separately and also issued together in the usual annual compendium of Acts Affecting Native Lands etc. ${ }^{167}$ A considerable number of Bills for 1893 were printed in Maori and survive in the Parliamentary Library Bill Books. ${ }^{168}$ As was by then usual the Acts

164 (30 July 1891) 72 NZPD 618.

165 (25 August 1891) 73 NZPD 574.

166 The other supposed Maori translations of Acts recorded by Willliams, are apparently spurious. Williams, 805-808. No Maori translation of the West Coast Settlement Reserves Bill 1891 (Taipua) has been seen, but it was the same Bill as Taipua had brought forward the previous year. Similarly no Maori copy of the Native Land Administration Bill 1891 (Kapa) has been seen, but this was a re-introduction of Taiwhanga's Bill of the previous year. It is possible that new Maori printings of these Bills were not made.

167 Williams, 834.

168 All of these are described in EMI but none were recorded by Williams. They are: Tongariro National Park Bill; Native Reserves Administration Bill; Imprisonment for Debt Abolition Bill; Distress for Rent Abolition Bill; West Coast Settlement Reserves Bill; Rohe Potae Investigation of Title Act, 1892 Amendment Bill; Fencing Act 1881 Amendment Bill; Rating Acts Amendment Bill (extract); Native Land Purchase and Acquisition Bill; Native Land (Validation of Titles) Bill; Wanganui Trust Act 1891 Amendment Bill; and Maori Real Estate Management Act 1888 Amendment Bill. 
passed by the session were cumulated and also issued separately. ${ }^{169}$ No Bills for 1894 were published in Maori but the usual collection of Acts was issued. ${ }^{170}$ The same thing happened the following year: no Bills were printed in Maori but the usual collection of Acts was provided. ${ }^{171}$ This was repeated in 1896 and $1897 .{ }^{172}$

Exceptionally a Bill in Maori was printed and circulated in 1898, the Native Land Settlement and Administration Bill 1898 but unfortunately no copy of it has survived. ${ }^{173}$ This is the last known nineteenth century printing of a Bill in Maori. Three passed Acts and their cumulation were also printed in Maori. ${ }^{174}$ In 1899 there appeared the usual collection of Acts and their separate issues, ${ }^{175}$ and in 1900 the same occurred. ${ }^{176}$

\section{NGA KORERO PAREMETE: MAORI MEMBERS' SPEECHES 1876-1906}

The lack of Bills printed in Maori in the last decade of the century may be accounted for by the fact that the Maori language in Parliament was no longer an effective means of parliamentary discourse; the Maori members used English as their primary language and perhaps saw no need for the translation service.

When Maori members first took seats in the House of Representatives their speeches were printed in Te Waka Maori and often copied from there and republished in Te Wananga. With the attempted suppression of Te Waka Maori late in 1876 concern was raised in the Legislative Council by Wi Tako Ngatata over the future publication of the speeches. He moved: ${ }^{177}$

That, inasmuch as the proceedings of Parliament and the speeches of Maori members are not published in the Maori language in Hansard, it is, in the opinion of this Council, very desirable

169 Williams, 854-868.

170 Williams, 883-883j. The annual compendium was overlooked by Williams.

171 Williams, 898-901g. The annual compendium was overlooked by Williams.

172 No Bills in Maori were issued in 1896, but the usual collection of Acts was produced (Williams, 914-924) and a similar compendium appeared the following year (Williams, 944).

173 Not in Williams, to be described in EMI. It was reprinted in facsimile in Native Affairs Committee "Report on the Native Lands Settlement and Administration Bill" [1898] IV AJHR I $3 \mathrm{~A}$.

174 Williams, 968-971.

175 Williams, 984-987.

176 Williams, 972, 988 and 1001-1005.

177 (26 October 1876) 23 NZPD 664. 
that every facility should be given to the publication and circulation of the Waka Maori, so that the Maori people may have some knowledge of what is done in Parliament."

Pollen, the Colonial Secretary, suggested that the speeches be reported bilingually in Hansard as an alternative. Whitmore acknowledged that he had been the originator of Te Waka Maori but deplored the fact that it had been turned into "a political engine." He therefore supported the notion that: ${ }^{178}$

the Maori speeches should be printed in Hansard in the Maori language. One race or the other must suffer the disadvantage of not being able to read those speeches; but, after all, he thought it was more important that the Maori speeches should be perpetuated in their own tongue.

After all, a good deal was lost in translation, and the Natives received no information from those speeches.

Hall supported the publication of speeches in Maori in Hansard but pointed out that there was no reporter to take them down in Maori, and suggested that there should be a separate Maori Hansard so that "they would be got out more rapidly and could be circulated only where necessary."179 Mantell observed that the English translations of speeches in Maori were "a very meagre interpretation of what was said by the Maori members." He suggested that Ngatata's motion be amended to read "That the speeches of the Maori members be printed in the Maori language, with a translation into English, in Hansard." 180 This amendment was accepted by Ngatata and agreed to by the Council.

Nothing further was done for three years until Henare Tomoana moved in the House of Representatives on 7 July 1880: "That the speeches of the Maori members delivered in this House be printed for circulation among the natives" arguing that this was necessary because of the demise of both Te Waka Maori and his own paper Te Wananga. ${ }^{181}$ Sir William Fox observed that as matters now stood Hansard contained "the speeches of Maori members as translated to the House" and lamented the fact that all earlier attempts to publish Maori newspapers had ended in failure because of lack of support from Maori themselves, a circumstance already alluded to by Tomoana in the case of Te Wananga which failed because of lack of funds. "Out of the forty thousand Maoris in New Zealand" said Fox, ${ }^{182}$

178 (26 October 1876) 23 NZPD 665.

179 (26 October 1876) 23 NZPD 665.

180 (26 October 1876) 23 NZPD 665.

181 (7 July 1880) 36 NZPD 55-57.

182 (7 July 1880) 36 NZPD 56. 
there were at least ten thousand who could read, or, counting the women, fully twenty thousand, and they should take some shame to themselves that there had not been a Maori organ in existence for many years past. [. . . ] It was quite clear that the Government could not interfere further than having the speeches of the Maori members printed in Maori in a sort of supplementary Hansard. As to the Government establishing a Maori journal, that had already been tried and been attended with very bad consequences and should never be attempted again.

These observations took place in the curious circumstance that the Government was determined to trim all expenditure and was considering abolishing Hansard altogether! After discussion the motion was referred to the Reporting Debates Committee. The Committee reported on 15 July 1880 and recommended: "that during the present session the speeches of the Maori Members be re-translated from Hansard and printed in a separate form, and that copies (not exceeding 500) be distributed equally among the Maori Members of both Houses of the Legislature." Again nothing was done and on 29 June 1881 Ngatata again raised the matter in the Council, moving: "That the speeches of Maori members delivered in this Council be translated from Hansard, and printed for circulation among the Natives." The following day Major Te Wheoro moved a similar motion in the House of Representatives but debate on the matter was adjourned until 14 July because of poor attendance. Both motions were adopted. ${ }^{183}$ The publication continued until 1906. A sample page is provide by Plate XII.

\section{CONCLUSION}

The period 1840 to 1890 saw vast changes in the status of the Maori language from being the primary medium of communication for the majority of the inhabitants of the country to being (as far as the political system was concerned) a largely ineffectual medium of communication. It could be used for diplomatic purposes on formal occasions, as exemplified in the case of Government translations to further the agenda of the Seddon administration, ${ }^{184}$ but it no longer served a useful function in the proceedings of

183 (29 June 1881) 38 NZPD 238, 239; (30 June 1881) 31 (NZPD 289; (14 July 1881) 38 NZPD 474.

184 The strangest example of this is Nga Korero o nga huihuinga o Te Kawana, Rore Ranapare (Lord Ranfurly), o Te Raite Honore Te Hetana (Rt Hon $\mathrm{R}$ I Seddon), Pirimia, Minita Maori hoki, me te Honore Timi Kara (Hon James Carroll), Memo mo te iwi Maori $i$ roto i te Kaunihera Maori, me nga rangatira Maori me o ratou iwi i o ratou kainga, i huihui nei mo runga i nga pire whenua Maori me era atu mea e pa ana ki te iwi Maori. 1898 me 1899. (See Williams, 1000; Bagnall, N3908). This work is a translation of: Notes of meetings between His Excellency the Governor (Lord Ranfurly). The Rt Hon $R I$ Seddon, premier and Native Minister, and the Hon James Carroll, Member of the Executive Council representing the Native Race, and the native chiefs and people at each place, assembled in respect of the proposed native land legislation and native affairs generally, during 1898 and 1899. (issued 1899 or 1900). See Bagnall, N3907). 
Parliament itself, or in the regular business of Government, as all the members of Parliament by then used English. ${ }^{185}$ When the Governor (Ranfurly) opened the session on 30 June 1903 he remarked: ${ }^{186}$

I am pleased to inform you that the greatest good feeling exists with the Maori race; that Mahuta Tawhiao Potatau Te Wherowhero has been called to the Legislative Council and appointed a member of the Executive Council. The estrangement of several of the Maori tribes which has too long existed is now closed, and Mahuta's influence will be of value to the Colony, especially in the early settlement of the lands of the Rohe Potae.

These sentiments were premature, as the looked-for "settlements" are still proceeding nearly a century later. When King Mahuta first spoke in the Legislative Council on 19 November 1903, members might as well have been listening to a speech by one of the four tame kakas of 1868. After a ceremonious preamble he merely asked that the Maori Councils Bill be put off until the following year, moved to his equally flowery poroporoaki and sat down. ${ }^{187}$ While this protocol was doubtless correct (tika) for the marae it did little to advance the cause for the Bill which was passed through the remaining stages forthwith. Ceremony was still at odds with substance, the besetting impediment to dialogue between the two peoples from the earliest time when Hobson had prematurely asserted "Now we are one people" (He iwi kotahi katoa) as he shook the hands of the Treaty signatories on 6 February 1840 .

It is right to recognise the sustained efforts of Walter Mantell to support the retention of the Maori language as a vehicle in which political discourse between the races could be conducted. This tikanga was initiated by Busby, Hobson, FitzRoy and Clarke in the early years of British colonisation but was abandoned, like the Treaty itself, in the administration of "good Governor Grey". It should be recalled in the 21st century as the revival of the language gains strength and people reflect on the continuing problems in the political expression of the Maori language. Despite the establishment of the Maori Language Commission in 1989 and the flourishing kohanga reo movement, te reo Maori is still in decline. In the Parliament of 2000 there are fourteen members who acknowledge Maori identity, of whom about half might be described fairly as fluent native speakers. Few of the other members of the House have even elementary familiarity with the Maori language.

Many observers of Parliament over recent years have been appalled at the poverty of expression of some of the Pakeha members in English, let alone in what to them are second

185 When the Proceedings of Parliament in Maori (Nga Korero Paremete, a translation into Maori from English) was terminated in 1906 there was not even a debate about it. 
languages. While a language can be brought back from the brink of extinction its reestablishment in a predator free environment is no easy matter as experience, in New Zealand with birds such as: kokako, kakapo, tieke, shows. It was the Maori newspapers, so many of which bore ornithological titles, ${ }^{188}$ which helped to keep reo Maori alive pending the legislation of 1989 . 


\section{DESCRIPTION OF PLATES}

\section{Plate I The Native Lands Act, 1865}

The long title, preamble and short title to the Act in English and in Maori. This is the first Act of the General Assembly to have been printed separately in Maori. Normally Acts were consolidated and printed as a volume at the end of the session.

The Native Lands Bill was introduced on 17 August by the Native Minister (J E Fitzgerald) as "a bill to amend and consolidate the laws relating to lands in which the Maori proprietary custom still exists and to provide for the ascertainment of the title to such lands, and for regulating the descent thereof [. . .]". It was probably distributed with copies of the "Maori Gazette" Kahiti Maori o Niu Tireni which first appeared in September 1865. A circular letter to the Civil Commissioner Te Waimate from Henry Halse (Acting Native Secretary) dated 23 June 1865 and transmitting thirty-four copies of "printed slips of the Schedule to the translation of the Native Lands Act which was inadvertently omitted when that Act was printed in Maori" and suggesting that they be pasted into the "Compendium of Laws affecting the Aboriginal Inhabitants" is among the Civil Commissioner's papers at Archives New Zealand, Auckland (BBIW 4808/3b). However both copies of the Act examined are printed with the schedule printed in the body of the work (p. 16), and the corresponding English text (pp 265-277) in the annual volume of Statutes in English also has the schedule. (Williams: 408, Alexander Turnbull Library).

\section{Plates II and III The Maori Representation Act, 1867}

This is the Act which resulted in the establishment of the four Maori seats. The first page of the Maori text (Plate II) and the first page of the English text (Plate III) are illustrated.

The existence of a Maori text of this Act was is confirmed by a return of Acts printed in Maori printed in the AJLC 1868 (pp 65-67) but the survival of copies was unknown until recently. One copy of the Act was found in the papers of the Resident Magistrate at Wanganui, Richard Woon (in Archives New Zealand, Head Office, MA-WANG series 4 no 9). It is accompanied by a similarly printed English text of the Act, also previously unknown. They are accompanied by an explanation of the Act published in the Kahitio Niu Tireni 1867 no 12 (6 November 1867) pp 75-76, with which the two Acts appear to have been issued, and with a circular from the Native Department to all Resident Magistrates, dated 23 October 1867 stating that the Maori Representation Act would be published "in the Kahiti with a general explanation of its character and provisions" and instructing them to ensure that it was circulated. The style of printing suggests that the Native Schools Act 1867 was distributed in the same way. Both Acts have also been found in a bound set of the Kahiti in the Parliamentary Library, here supplying the place of pp 77-80 of that copy of the Kahiti. (By permission, Archives New Zealand: not in Williams). 


\section{Plate IV The Native Lands Frauds Prevention Act, 1870 (Extracts in Maori)}

An Act "to prevent improvident dealings and frauds upon the alienation of land held by natives".

A summary of the Act rather than a translation, some clauses being omitted. The short title is given in the second paragraph of the text. In the 1870s and 1880s it was sometimes that case that only the clauses "particularly affecting the native race" were printed and published and what did or did not 'affect' the Maori was something of a mystery. The extract given here was issued about September 1870 at the time of the publication of the English version which was printed with other Acts as a supplement to the New Zealand Gazette. (Williams: 453, Alexander Turnbull Library).

\section{Plate $V$ The Timber Floating Act, 1873}

This is the form in which most Acts printed in Maori were issued, with the Royal Arms and Analysis in full and with shoulder notes. In the present instance the regnal year and the Act number are in the heading, although they were normally omitted. In many cases, however, not all these elements are present.

"An Act to authorise the use of rivers, streams and tidal creeks for floating timber and other substances"; essentially to permit the floating of kauri logs. The potentially damaging effects on Maori fisheries and riparian property are discussed in the Committee of the House debate on 10 September (NZPD vol 15 pp 1006-1010). A Timber Floating Bill (probably 68-1) was introduced and discharged by the Premier (Vogel) on 18 August, and replaced with a new shorter Bill of five clauses which was sent to a select committee. The original Bill had explicitly authorised the construction of kauri dams but it was stated at the introduction that the new Bill neither authorised dams nor prohibited their construction. The Act as finally passed removed the clause added in the Council which would have restricted the application of the Act to the province of Auckland. The Bill reached the third reading in the Lower House on 10 September and a third reading in the Council on 22 September. According to the schedule of bills printed in Maori (AJLC 1873 no 16) no Maori version of this Bill appeared, but Maori objection to it was expressed in a number of petitions. (Alexander Turnbull Library; not in Williams).

\section{Plate VI The Native Councils Bill, 1872}

A Bill introduced by the Native Minister Donald McLean but later withdrawn. This is the first Bill to have been printed in Maori. The elements printed are the caption title 'Kaunihera Maori', then the intitulment and long title then the enacting words 'Ko tenei ka hanga .... The English words at top right are the shoulder note.

"A Bill intituled An Act to make provision for the Constitution of Local Councils in Native Districts, and to define the Functions and Duties of such Councils." (long title from 
the English text of the Bill 1872 No 119-1). McLean's Native Councils Bill, 1872 was discussed in the House of Representatives on 22 October 1872. It was intended to allow the settlement of disputes between Maori in selected Native Districts by means of Maori Councils instead of by the British legal courts. The Minister said it would "only be brought into operation in cases where the majority of the Natives in any particular district desired it." (NZPD vol 13 p 895). Successive members asked McLean to hold the Bill over until the next session, Swanson suggesting that it be circulated among Maori but withdrawn for the time being. McLean assented and withdrew the Bill. This version of the Bill differs in some respects from that published in Te Waka Maori o Niu Tireni vol. 8 no 21 (30 October 1872), and may represent a second draft. A copy of the Bill is among McLean's papers (Alexander Turnbull Library MS-Papers-0032-0118). (Williams: 474, Alexander Turnbull Library).

\section{Plate VII The Maori Representation Acts, 1867 and 1872 Amendment Bill, 1873}

H K Taiaroa's second attempt to increase the number of Maori representatives in the House beyond the minimum of four. The elements printed are a centred shoulder note (in English), a caption title, the Analysis (here given in two columns and complete, but usually omitted when Maori bills were printed), the intitulment and long title and a preamble and then the enacting words (the Matua korero). The 'ingoa poto' is the short title. Marginal notes are present but these were often omitted.

This Bill sought to make provision for an increased representation of the Maori people in Parliament and divided the Western and Eastern Maori districts into three electoral districts. It was introduced on 15 September 1873 and had a second reading on 22 September, when it was made clear that it would not be enacted. Taiaraoa withdrew the Bill on 30 September. No copy of the English text of the Bill is known (1873 No 132-1). The Maori text has an incomplete Bill number: "No - .". It was probably printed on or about the day of introduction. (Alexander Turnbull Library; not in Williams).

\section{Plate VIII The Sheep Act, 1879 (Extracts)}

The Sheep Act, 1878. (so far as the same applies to the Maori Race.) Nga tikanga o "Te Ture mo nga Hipi, 1878," e paa ana ki nga iwi Maori (from the caption title). The English long title is "An Act to provide for the eradication of scab in sheep."

This is an example of an Act in which only the clauses 'affecting natives' were printed in Maori: clauses 1-2, 5, 9, 11, 13-17, 19-33, 38-46, 49-50, 52-54, 58, 61-61, 64, 68 - and four Schedules. The page illustrated shows the deliberate omissions by lines of asterisks. (Williams: 549, Alexander Turnbull Library).

\section{Plate IX The Maori Representation Bill, 1879}

"A Bill intituled An Act to provide for the Representation of the Maori People in the House of Representatives." (long title from the English text of the Bill, 1879 No 31-1). The 
Maori text of this Bill lacks the Analysis section usually found in Bills, as well as the shoulder notes and the printer's number "No 31-1" found on the English printing. This Bill was a companion Bill to the Qualification of Electors Bill, both being introduced on 28 October 1879. From the statements made by the Premier (Hall) on 31 October, however, it is clear that the Maori Representation Bill was not printed in Maori until early November, probably just before the second reading on 4 November (NZPD vol 33 pp 74-75).

The Bill provided that the number of Maori members would be proportional to the number of non-Maori members in the same way that the proportion of registered Maori voters was proportional to the number of registered Pakeha voters. Maori would not vote for European candidates nor would Europeans vote for Maori candidates. According to Hall the number of Maori members should therefore increase to about six or seven. But as Major Te Wheoro pointed out "such was the reluctance of Maori to register" [as voters] that it would have the opposite effect. The Native Minister, Bryce, agreed that this was a serious objection to it and the Bill was dropped, the Qualification of Electors Bill being amended consequently to provide for the continuation of the existing Maori electoral provision (NZPD vol 33 pp 81-83). (Alexander Turnbull Library; not in Williams).

\section{Plate X The Qualification of Electors Bill, 1879}

"A Bill intituled An Act to define the qualification of electors of members of the House of Representatives." (long title from the English text of the Bill, 1879 No 23-1).

The Bill was introduced on 28 October 1879 and the second reading took place on 31 October, on which occasion the Premier (Hall) said: "With regards to the Maoris, we do not propose that they shall vote under this Bill at all. They are provided for under a separate Bill which, I trust, will be found as satisfactory to both races as any such measure can be."(NZPD vol $33 \mathrm{p} \mathrm{11).} \mathrm{The} \mathrm{Bill} \mathrm{removed} \mathrm{the} \mathrm{right} \mathrm{of} \mathrm{Maori} \mathrm{to} \mathrm{vote} \mathrm{on} \mathrm{the} \mathrm{general} \mathrm{roll,}$ confining Maori to vote under the "special representation" provisions in the Maori Representation Bill 1879.

The only version of the Bill printed in Maori which has been seen is not that used for the second reading (No 23-1) but corresponds to No 23-2 "as reported from Committee of the whole house, 11th November, 1879" (although other versions in Maori may have existed). This version is significant because it gave limited voting rights to women - a fact reflected in the Maori printing as well as the English printing. On the 14 November, however, the Bill was recommitted and the words "every person" ("Katoa ia tangata [...]") was replaced by the word "man" ("Katoa ia tangata tane [ . . ]") once again. Version 23-3 of the Bill has not been seen, but version $23-4$ as passed by the House and as amended by the Legislative Council exists in an English version. Ultimately the Act allowed Maori males over the age of twenty-one who were enrolled on ratepayers' rolls or who held a property qualification ("who is seized in severalty of a freehold estate of the value of 
twenty-five pounds whether subject to incumbrance or not") to vote as electors. NZPD contains extensive debates on the Bill, which received the assent on 19 December. (Alexander Turnbull Library; not in Williams).

Plate XI Native Land Acts (in English and Maori) ... 1888

A compilation of eight Land Acts in both English and Maori texts, the English text placed before the Maori.

A similar publication containing four Land Acts had been issued in 1886, but there appears to have been no equivalent publication for 1887, in which year only two such Acts appeared. The so-called "Maori Gazette" (Ko te Kahiti o Niu Tireni) advertises both the 1886 and 1888 publications from October 1888, but never mentions an 1887 issue. The practice of issuing collections of Acts became regular from 1889 under the title Acts affecting native lands, and this annual compilation continued until 1910 with a gap only for 1891 . (Williams: 759a, Alexander Turnbull Library).

\section{Plate XII Nga Korero Paremete}

Extract of speeches by H K Taiaroa in the Legislative Council on 27 August 1890 from Nga Korero Paremete (Maori Members Speeches') a collection of speeches published annually from 1881 to 1906 .

Unfortunately for philologists these speeches are not verbatim records of what the Maori members said. The speeches given in Maori were translated by the official interpreters and these form the basis of the English texts as given in New Zealand Parliamentary Debates (NZPD). The versions given in Nga Korero Paremete are backtranslations into Maori from the English texts of the speeches. The Governor's speeches on the opening of Sessions were also translated into Maori and are included in Nga Korero Paremete. (Alexander Turnbull Library). 
Whateiggotase He 'Ture hei whakatikatika hei whakaputahi i nga Ture e whai tikanga ana ki runga ki nga whenua i roto i te Koroni e mau tonu ana ano $i$ runga $i$ ta te Maori tikanga pupuru o namnta hei whakarite hoki kia mohiotia ai te tuturutanga o nga whenua Maori a hei whakatakoto tikanga mo te whakataturanga iho o nga whenua matua mo era atu mea hoki. [Akatopa 30, 1865.]

Yataskonem $\mathrm{No}$

NO TE MEA he pai ano kis whakntikatiksia kis whakaputahitia nga Ture whaksoti tikangs whenun $i$ roto $i$ te Koroni $\theta$ tau tonu ana ano ki aua whenua nga tikanga pupuru a'te Maori hei whaknrite hok kia mohiotin ai nga tangata e purutia ana e ratou aua whenua'i rung aua ritenga hei tautoko ake $i$ tetahi tikangs hou hei tinei i tau tikanga pupuru a hei whakatakoto i tetahi ritenga mo tausi tikang upuru o namata kia whakarerea kin mau anake to whenua i rung te Karauna Karanti bei whakntakoto tikanga hoki mo te whakataturanga o nga whenua matus ina mahuetia taua ritenga pupura o namgt a hei whakatakoto $i$ etahi atu tikanga mo runga mo anei mea kua whakahuatia nei.

Na kia Meisga hei Tune e te Runanga Nui o Niu Tireni i tona huihuingra i roto i te Paremete nei i runga hoki i te mana o tan Runanga nga ritenga i raro iho nei.

Ingow lota. I. Ko te ingoa Poto o tenei Ture ko te "Ture mo nga whenua Maori

The Native Lands Act, 1865
Av ACT to Amend and Consolidate the Laws relating to Lands in the Colony in which the Maori Proprietary Customs still exist and to provide for the ascertainment of the Titles to such Lands and for Regulating the Descent thereof and for other purposes.

[30th October 1865.]

is expedient to amend and consolidate the laws relnting to lands in the Colony which are still subject to Maor proprictary customs and to provide for the ascertainment of the persons who according to such customs are the owners thereof and to encourage the extinction of such proprietary customs and to provide for the conversion of such modes of ownership into titles derived from the Crown and to provide for the regulation of the descent of such lands when the title thereto is converted as aforesaid and to mak further provisions in reference to the matters aforesaid

BE IT ENACTED by the General Assembly of New Zealand in Parlia ment assembled and by the authority thereof as followo

I. The Short Title of this Act shall be "The Native-Iands Act 1863."

The Native Lands Act, 1865

PLATE III

New Zealand.

ANNO TRIGESTMO PRIMO

VICTORIA REGIN AE.

No.

AN ACT to provide for the better Repre- nith sentation of the Native Aboriginal Inhabitants of the Colony of New Zealand. [ October, 1867.

W HEREAS owing to the peculiar rature of the tenure of Maori land mamenth and to other causes the oative aboriginal inhabitants of this Colony of New Zealand have beretofore with few exceptions been unable to become registered as electors or to vote at the election of members of the House of Representatives or of the Provincial Councils of the asid Colony and it is expedient for the better protection of the interests of Her Majesty's subjects of the native race that temporary provision sbould be made for the special representation of such Her Majesty's Native subjects in the House of Representatives and the Provincin Colony

BE IT THzkrForz Exactro by the General Assembly of New Zealand in Parliament assembled and by the authority of the same as follows1. The Short Title of this Act shall be "The Maori Representation surt Tilo.

2. The term "Moori" in this Act shall "mean a male aboriginal native inhabitant of New. Zealand of the age of twenty-one years and upwards and shall include half-eastes.

3. In addition to the number of members of which by any law for Four ycont anber the time being in force it may be provided that the Honse of Representatives. shall consist there shall be four members of the er represent therein the inhabitants of the Colony of the Haori race. 4. For the purpose of the election of such members of the said piriaion w oclowy

House the Colony shall be divided into four Mari electoral districts.

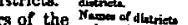

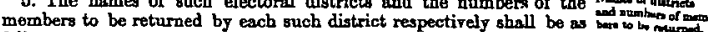
follows-

The Northern Mnori Electoral District-One member.

The Eastern Maori Blectoral District-One member.

The Western Moori Electoral District-One member.

The Southen Mrori Electoral District-One member.

6. Such members shall be chosen respectively from amongst and Hor chem by the votes of the Maoris inhabiting each of the said districts who shall not at any the theretoforo have beca attainted or convicted of any treason felony or infamous offence and shall be otherwise qualified as hereinafter provided. 


\section{DE TURE TEYEI MEI ARAI I TE MAII HOKO TAEAE I NGA WIIENLA O NGA MAORI.}

Fe molistanga kua mahia ohoreretia te hoko. te reti, te moketi whenuat etahi tangata, i nunga i te mea ko o ratou ingoal anake $i$ uru ki nga Carauna karanti, knia i whakaarohia ai kia whakatakotoria he ture ei ari i aus mili.

ko te ingan o tenei Ture, ko "Te Ture ami i nga mali tabac ki ga Whenua Mlanri, 1S70."

Ma te Kawana e panui nga takiwa, e karanga looki kia tau te ana o tenci 'fure ki aua takiwa, kei a ia ano lioki to whakaaro ki to anui hou $i$ nga role, $k i$ to tango mai ramei $i$ ctahi wahi o aua takiwa roto i te mana o tenei Ture.

Ira te Kanana e whakatu he tangata lici Komihana mo tc takima ntahi mo ngat takiwa ranei ina panuitia hei takiwa $i$ runga i teuei ure, a mana te whakaaro ki te whakamutu i tera tangata ki te bakatu i trala hei riwhi mona.

E knre te hoko, te reti, te noketi ranci o te whenua kua tuturu i te Mtanti e mana, melamenca kahore i tino tik:t nga ritengal katoa o ua mahi ; a melienica lic kai-tiaki kau te tangati mo tetahi tangata a mali lic in i runga i tana kai-tiakitanga, ckore tana hoko, moketi, eti mncir maila; a meliemen, he waipiro, he pu, he paura, he hot: c tingara he mea pera te utu mo te whenua, he wahi ranci o te uta, zore c mana to hoko, te reti te moketi rnnei.

IIa te Komilana e ata kini marire nga ritenma o aua mali, mana titiro mehemea e tika ana te hoko te reti te moketi, $\mathrm{c}$ lic ana ranci, mehemea hoki e marama ana ngia tangata e hoko ana c reti ana oketi ana mnci i te nhenua hi uga liupu o te pukapuka c whakaangia ai o ratou ringaringa; mana hoki $c$ ata kimi mclemea c tika na tc utu e karangatia ana hei utu mo te whenua, mehemea hoki o e ana ano he whenua mo nga Maori e uru ana li tava mahi hoko, ti, mokcii ranci.

MIchernca ka tuturu te moliu o taua Komilanna e tika ana, heo e tuli $j_{2}$ i tana kupu ki runga $\mathrm{ki}$ te pukapuka tuku, reti, nokcti nei.

Mehemea la whokaaro tetalii taugata kua raru in i runga $\mathrm{i}$ to ahi o taua Komilhana c pai ana kia whai kupu ia ki te Hupirimi looti, kn nga ritenga mo tenci ka ata whakatakotoria ka panuitia. Nia ka rongo te Hupirimi hooti ki te kupu a tau tangata, melieea ka whakaaro taun hooti kua tika te mahi a tau Komihana kua - ranci c pai ana hia whakaputaina to kupu e tc Kooti IIupirimi a katia te hoko, te muncli, $i$ reti ranci a +..... +aisgata $i$ te whenua, alakanctia ranei.

E jni ana kia wlinkaritea e Te Kawana raua ko tctali o no ai-whakawa o 'le JIupirinni Kuoti etahi ritenga hei whakahaere mga i te mana o fenci Ture, a ka oli ka panuitia ki te Lílhiti l'akeha rite tonat te manal ki te mana o te Ture.

Melienca ka korero tito te tangata i te taima $\mathrm{c}$ korero ana ia i to aro o te Komihama, e tika ana kia whiua ia $c$ te lure mo tana rero tito i rumsa i te mea kua ontitia ia.

E pai ana Eja whakaritea c Te Kawana nga moni kia utua ki to onilinus e nga tangata $\mathrm{c}$ tae ana hi toua aroaro ki te korero, leoi ka te wlinkarite, ma nga tancrata c tac ana ki te Komilana e utu.

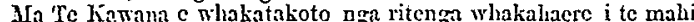
nga Komihana i runga i tenei Turc, mana e whakamutu cra, c hakatakoto he ritenga hou, kei a ia tena. lin oti te whakatakoto taia ki te Kahiti Pakeho.

Grozce: Didsncry, Kaitta o te Knarnatanga, Poncke, Nia Tireni.

\section{The Native Lands Frauds Revention Act, 1870 (Extracts in Maori)}

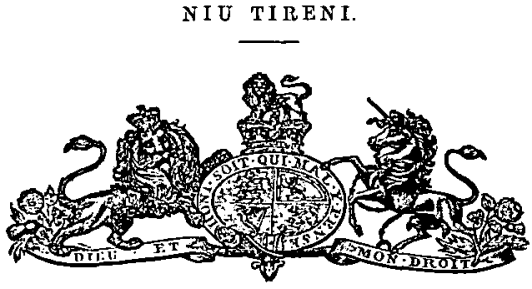

TAD TORD TEKAU MA WHITU

\section{K U I N I W I K I T O R I A.} Nama XXXIX

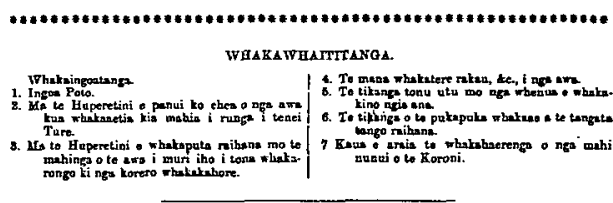

HE TURE hei whakase mo nga awa me nga awa hoki waskevingetenge. e paringia ana e te tai kia tukua ki etahi tangata he mana mo te Whakatere Rakau me era atu mea. [Hepetema 29, 1873.]

NA TENEI Ka HANGa e te Runanga Nui o Niu Tireni kua N luihui nei ki te Paremete $i$ runga boki $i$ te mann o taus Runanga nga ritenga kua tubia ki raro nei.

1. Ko te ingon poto mo tenei Ture ko "Te Ture Whakatere Ingon Pow Rakai, 1873."

2. Ala nga Huperetini o ia Porowini o ia Porowini e panti i Ma te Hupretiai $_{0}$ ia takiwa $i$ in takifa i roto i te Kahiti o te Porowini ko ehea ranei nga parai ko ehen on awa $\mathrm{i}$ roto $\mathrm{i}$ taus Porowini kun whakanetin i runga i te Raihana, ka kis nasias i rage $i$ korerotia i muri nei, kia mabis i raro i tenei Rure, a mana hoki e teoci Tare janui te mutunga o te mann o te Railana i tukua ki tetahi tangata mo aua awa; a ma te putanga o taun panui e whakamntu te whakater rakau i tana arra, i aus ara maei.

3. Mehemen ka hiahia tetahi tangata ki te whakatere rakau $i$ ase to Eapertivi tetalui awa, i tetnhi awa ranei e paringis ana e te tai, i runga i nga thakpats nihas tikanga o tenei Ture, me pa atu ia $\mathrm{ki}$ the Huperetini o te Porowini mo te making o to

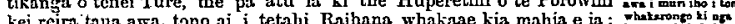
kel reira taus awa, lono ai tetalli Rahna whakase kia mahia e ia

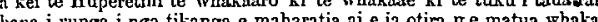
matura thakaputa $\mathrm{e}$ in tana pauni hei whakaafu ki nga tangata no ratou te whenus i nga tahatalia o taus awa awawa ranei uga tangata ranei e nobo ana ki reira kua tono tetahi tangati $i$ te railiana a me whakarongo in $k$

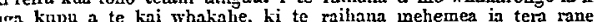
be tangata c whokalic aua.

The Timber Floating Act, 1873 


\section{Kaunihera Maofi.}

\section{HE TURE I HUAINA.}

He TURE hei whakatakoto Tikanga mo nga Kaunihera. i nga Takiwa Maori, a hei whakatakoto Tikanga : hoki te Mahi o aua Kaunihera.

KO TENEI JA HANGA e tè.Runanga Nui o Niu Tireni kua 1. huihui mai nei ki roto ki te Paremete i runga i tona mana e tuhi i muri nei :-

1. Ko te Inga Poto mo tenei Ture ko "Te Ture Kaunihera" Maori, 1872," a ko te welewehcnga o taua ture kei muri iho nei :Mrori.

WAHI I.-Ko te Whakaritenga Kauniticra mo nga Takiwa

WABI II.-Ko te tu Taugati hei Pooti Takiwa, me te Pootitanga o nga Mema mo te Kaunihera.

\section{WAHI I.}

KO TB WHAKARTTENGA KAUNIHBRA MO NGA TAKIWA MAORI.

2. A te korerotanga o tenjei Ture, ka kitea'nga kupu c mau ake nei, na ko nga tikanga enei,-

Ko te kupu nei "Takiwa Maori" "takiwa," ranei ko nga Takiwa

ka whakaritea $\mathrm{i}$ raro $i$ tepei Tuxa nga Kaunihera Maori e whakaritea i raso iho nei, he tangata ranei e phakaritea ana hei Tiamana i nga huinga - te Kaunihera hei whakakapi mo te Tumuaki.

"Kaunihera" he Runanga Tangata Maori e pootitia ana mo is takiwa, mo ia takiwa i raro i tenei Ture.

"Tangata" ko nga tangata o te I wi Maori hui tahi ki inga hawhe.kaihe o tana iwi.

3. He tiks ki ta te ture kaua e iti iho ì te nga tangata o te iwi Maori e noho ana i nga takiwa o te motu nei, $c$ tau tonu ana te mana Maori $i$ runga hi te mea ranei e nui ake ana nga tangata o te iwi Maori, mehemea ka tukn pukapuka ratou ki a te Kawana kia whakaritea a reira hei Takiwa Maori ki raro i nga tikanga o tenei Ture.

4. Me whakastu mai $i$ roto $i$ aua pukapuka nga rohe mo taua takiwa, me te tokomahatanga, o nga tángata o roto i taua rohe, i runga $i$ te whakaaro; he tika ki te ture ma te Kawana ratou ko tana runanga i te mea ka whakaae ia ki aus rohe, e whakatu tau takiwa hei Takiwa Maori i raro i tenei Ture, mana hoki e tapa he ingoa mo taun takiwa.

5. I runga i taua tono ka tika ki te ture ma te Kowana e whataiti e whakanui ranei nga rohe; a e tika ana hoki ki tenei Ture kia whakahoutia is wa, ia wa, nga takiwa, ki te whakakore ranei.

6. Me tu he Kannihera i ruro i tenei Ture li ia takiwa, ki is takiwa, kana $e_{\text {e }}$ iti iho nga mema $i$ te toko-ono, kaua hoki e nui ake $i$ te tekan-ma-rua me pooti i roto i nga tangata o te takiwa i runga i-nga tikanga e tuhi i muri nei. A ma te Kawana e whakatuturu te tokomahatanga o nga rohe. Ko te ros o te wa e to ai taua Kaunihera kia toru tan, hei te ra tuatahi tonu o te pootitanga timata ai. A ki te pau

The Native Councils Bill 1872
[MAORi Repregentation ACt AMgNDMBNT.]

To Ture Whakatikatika i nga Ture whakstu tangate Maori mo roto $P$ te Paremete.

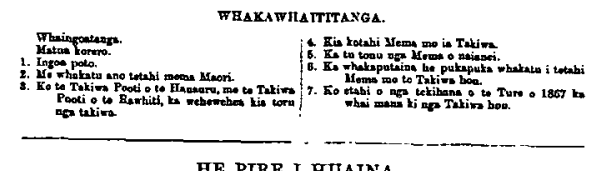

HE PIRE I HUAINA.

HE TURE e whakatakotoria ana hei whakatokomaha ake whinguatang i nga tangata Maori mo roto i te Paremete.

NOTEMTra o tika gas kis whakaturia he tikanga hei whakatomaks Na tenci kn hanga e te Runato i te Paremete.

Na tenci kn hangas e te Runanga Nui o Niu Tireni kua huibui satus torem 5 nga ritenga kus tuhis i raro nei :-

1. Ko te ingos poto mo tenei Ture ko "Te Ture Whakatikatika i topos pee.

nga Ture whakatu tangata Mrori mo roto i te Paremete 1867 .ika to Ture Whakntu tangata Maori mo noto i to Yaremeto 1870 , me Te Ture Whakatikatiks 1873."

10 2. Kua oti te whakatu i nga Mema tokowha, i kowhiria i runga

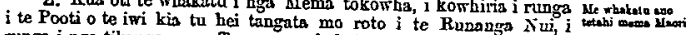
runga i nga tikanga o aus Tore, me whakatu ano $i$ tetahi atu Mema kia kotahl i runga i nga tikanga o tenei Ture, hei whakahaere i nga tikanga ki te taha Mrari o te Koroni i roto i to Whare Runanga No. -

The Maori Representation Acts, 1867 and 1872 Amendment Bill, 1873 
A ki te mea ka malue te mahi whakaria i whakawa ai te tangata

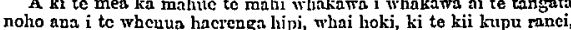

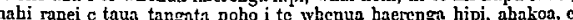
kore aus mea o kiin, ma reira c lore ai he wlakawa a to kaiirotiro lipi, kin puta

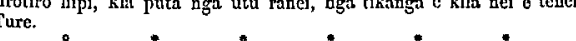
64. Ki te mea ka whakawakia te trngata ki uga tikanga o tenei To leggata okik. ure, mo nga hipi, a ka kil aia, c hara i air aua hipi, a ki te mea ranei, ahua awngawanga ani te whakjaro ki nga hipi, nania ranei, ara, ga hipi e whakamakia ana i te aroaro o te Kooti, ki te tikanga o tenel ure, penci, ma nga Kni-whakawa Tatihi o te Píhi e mea, ko te angata nana aun hipi, na te ahua o aua hipi $i$ alo ake $i$ te ahua o to parani, me te korero a te kai-tirotiro hipi, me nga korero a to hunga e whaaki korero ana i te aroaro o te whakawa mo aub hipi, a ma ma Kai-whakawa e mea kia utua nga moni $e$ kiia nei mo te hara, mo e utu mo te whaknwakanga, me utu $i$ nga moni o nga hipi ana hokona ahi o aun hipi ki te tikanga o te kupu kii a aua Kai-whalenwa kia sokona etahi o aua hipi, a ki te kore o ea aua moni, me hoko ano be hipi, a ki te kore e ea aua moni i era, penei, me kii he moni kia riro nai i etahi taonga ano a te tangata nana aua hipi.

68. Ki te mea ka mohio te kai-tirotiro hipi, he hipi ano kei tetahi $\mathrm{g}_{\mathrm{g}}$ hipi o mas kima o muia ana o te kutu, penei mana ma taun kaj-tirotimo hipi te eto ketu phakaaro mo nga mahi e mahia ki aus hipi kia kore ai ho katu i ana ipi. A ki te mea e kore c mahia nga mahi e te tangata nana ua hipi, e kore ai lie kutu $i$ aua hipi, penei, he mea tika ano kia mahia ga mabi e kiia nei e tevei Ture e to kai-tirotiro hipi kja kore ai ho cutu $i$ aua hipi, ano i mahia ki to tikanga e kiia nei mo nga hipi mate te hakihaki. A ka mana ano to kii a taua kni-tirotiro hipi, ki te mea a kiia eia ata hipi he hipi kua pangia c te mate, a ki to mea ka kïa ra lipi he hipi mate, jenei, ko te utu e utu ai te tangata nana ua hipi mate i te kutu, me nga tangata ke atu ranei, ko nga utu, me e whakabe o tau ana i te Kooti ki te tangata unna nga hipi mate $i$ te hakihakj.

\section{The Sheep Act, 1879 (Extracts)}

\section{PLATE X}

Te whakatikatikanga o nga tangata hei Kai-pooti.

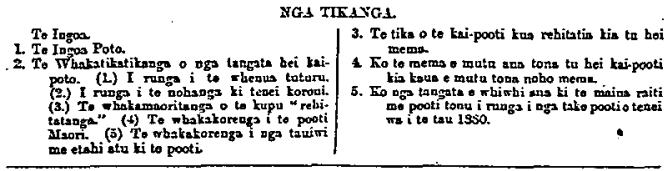

HE PIRE KO TE IXGOA

He Ture hei whakarite i te tika o nga tangata kaipooti mema mo te Whare Runanga Nui.

KLA meingatia hei ture e te Runanga Nui O Nui Tireni, e noto K huihui ana $i$ roto i te Paremete i raro ano i tona mana, nga tikanga e whai ake nei :-

i. Ko te ingoa poto o tenei Ture ko "Te Ture mhabatikntikanga o nga Tangata kai-pooti 1579."

2. Ko nga mema mo te Whare Runanga Nui me whirimliri mai $i$ ia takinil kua oti te whakarite he Takiwa pooti, $i$ runga i nga pooti a nga tangata e noho ana $i$ roto o Nin Tireni, a e nhiwhi ana $i$ ona takiwa hi nga huarabi pooti e whakariter and e tenci Ture ana.

(1.) Katoa is tangata e tate ana ona tau ki to rua te kau ma tali hipa atu ranei, be whenua tona nona ake e man ana ki a ia i roto ano i te talsima pooti e puta ai tona pooti, a e tae ana nora utu o taua whenus ki te rua to kau ma rima pauna, alrakoa he mer a te ture kei runga e tau ana, a kua tuturu $k i a$ ia kna whaitake ia i runga i te ture me to tika $a$ kua ono nga marama e mau ana $\mathrm{ki} a$ ia taus whenua $i$ mua atu $i$ te rehitatanga o tona pooti; tetahi

(2.) Katoa ia tangata tane e tac ana ona tau ki te rua te kata ma tahi hipa atu mnci kua kotahi tau e nolıo ana i roto $i$ te koroni, a kua ono marama $i$ roto $i$ te takina pooti e tono pooti ana in. Na ki te korc in e rehitatia i raro i te hmamali whiwhi whenua o tenci Ture mo taua takira, c tika ana ia kin rehitatia hei lai-pooti, a kia-pooti in i nga pootitanga mema o aua takiwa wo te ivlare Runanga nui. 
Ko Wikitori A, te Kuini o Ingarani, i tana mabara atawai ki nga Rangatirg me nga Hapu o Nu Tirani, i tana hinhin hoki kia tohungia ki a ratou o mou rangatiratanga, me to ratou wenua a kis mau tonu boki te Rango ki a ratón me te ars noho boki, kua waksaro ia he mea tika kia tukus mai tetahi Rangatirs hei kai wakarite ki nga tangats moori o Nu Turani. Kie waksaetia e nga Rangutira maori to Kawanatunga o to Kuini, ki nga wahi katoa o te wenua nei me nga wutu. Na lo meg boki he tokomaha ke nga tungata o tona i $i$ kua noho kị tenei wenua, a o ohaere mai nei.

Na, ko te Kuini e hiahin ana kia wakarites te Kavienatangen kik kaus ai ngai kino e puta mai kj te tangata mani kj te pakeha e noho turie kpre ana.

Na, kua pai te Kuini kin tukun a hau, a Wraemu Hopirosa, be Kapitana $i$ te Roiare Nawi, bei Kuwana mo nga wabi katoa o Nu Tirnni, e tukn aianei amua atu ki to Kuini ; e mes atu ans is ki aga Rangation o to Waka minenga o aga Hapn o Nu Tirani, me era Rangatira atu, enei ture ka

Ko te tuatahj.

Ko nga Rangatira o to Wakaminenga, me nga Rangatira katoa hoki, kihai i uru ki taue Wakaminenga, ka tuku rama atn ki te Kuini o lingarni ake tonu atu te Kawanatenga katos o o ratou wenua.

Ko te tuarua,

Ko te Kuini o Ingarani ka wak̆arite ke wakage $\mathbf{k i}$ nga Rangatiza, ki nga Hapu, ki nga tingata kntos o Nu Tirani, te tino Rangatiratangas o o rato

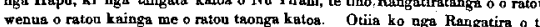
Wakaminenga, me rga Rangatira katos atu, ka tuku ki te Kuini te bokonga era wabi wenua e pai oi te tangats nona te wenua kj te ritenga o te uto e wa ritea ai retou ko to kai hoko e meatia nei o te Kuini hei kaj hoko mona.

Ko te tuatoru,

Hei wokaritenga mai hoki tenei mo te akanetanga ki te $K_{\text {awanatanga }}$ o te Kaini. Ka tiakina e te Kuini o Ingarani nga tangata maori katoa o N Tirani. Ka tukua ki a ratou nga tikanga katos rite tahi kj ana mea $\mathbf{k i}$ nga tangata o Ingarani.

WILLIAM HOBSON, Consul \& Lieutenant-Grovernor.

$\mathrm{Na}$, ko matou, ko nga Rangatira o te Wakaminenge o nga Hapu o Nu Tirani, ka huihui nei ki Waitangi. Ko matou hok' ${ }^{\prime k}$ nga Rangatira o N Tirani, ka kite vei $i$ te ritenga o enei kupa, la tangohia, ka wakeaetia katoatis e matorit. Koia ka tohungia ai o matou ingos o matou tohi.

Ka meatis tenei ki Waitangi, i te ono o nga ra o Pepuere, i te tau kotahi mono, ewaru rau, ema tekau, o to tatou Ariki.

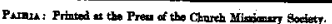

Native Land Acts

(in English and Maori)....1888 aej mo nga Rahui o te Tai Hallauru ki ma te Kawanatanga me tono ki a Tagga tikanga katoa i runga i nga whaka- whiao a ki te whakaae ia tera pea nga tuga a nga Apitireita ara nga Kai- Maori $\theta$ whakaae. No nga tikanga wihiriwhiri o muri nei kia pau katoa tenei o taku Piro Whakahaere Whenua mai ai nga kaute a taea noatia tenei ra. Maori e mau ake nei :-

Whakagetia ana.

PIRE MO NGA MAHI NUNUI. TAIPUA.- E te Tumuaki ko etahi tetiona o tenei Pire e pa ana ki nga Ifrori, a ki taku whakaaro he mea tika bia whakatikatikaia. Ka pai ahau mehemea ka whakaritea $\theta$ te mems nana agi $i$ kokiri $i$ tenei Pire kia panuitia nga pohoanga o te Kooti ki roto i te Niu Fireni Kahiti mo te Kahiti kia tino wohio ai nga Maori. He mea tika kia mi to panuitanga o nga nohoanga o te Rou to panuitanga o nga nohoanga o te hoot hei whakarongo i nga tono mo nga whenta e tangohia ana ano nga naki nunui. E hiabia ana hoki ahau
kia whiriwhiria e ia tetahi tikanga tiaki hia whiriwhiria e ia tetahi tikanga tiaki (inga urupa Maori me etahi atu wah he aui nei ona tikanga kj nga Maori kia
kore e takahia hahua koretia $\theta$ te ta agata. Ka tukia e shan a.ku menemana ki te Minita mo nga Mahi Nunni ins tukune enei take kia Komititis. He mi to owhiti o nga Maori ki nga mahi polkanoa a te tangata ki te taka kino i o ratou urupa. A e hiahia ana ahau kia tioo tau tetahi tikanga mo runga $i$ enei mea kia kore ai e puta he raruraru a wari ake nei. Mohemea e tino mara ms ana te Ture mo runga $i$ enei mea * ore puta he rararari ina tonoa h gar mo te wawahanga i nga taiepa mo gat mo te wawahanga i nga taieps me ganui tuarua.

REREWE NUI O AOTEAROA

TAIWHANGA.-D te Tumuaki $h$ torgata tautoko tonu ahau kis hang tererewe e nga wa katoa. Kua ki ano than kis kore nga rerewe me nga ron thore kan he tikanga o nga whenua. Trangi mo rungs i tenei take me matua rhakare a Tawhiro. Kua maha aku titenga i \& Wahanui i Akarana a i ki son ahau ki aia ki to tohe tonn ia ki te waku i nga whenua o Waiketo kia thakswakia e te Kooti Whenua Maori tia ahei ai ia te hoko e aus whenua e kore a tika no te mea kei raro taua taWra $i$ te Tiriti o Waitangi, a kei raro te mana o Tawhia. Ko te mea tika 8. miti, Ko ng tikan miti, 1886, me pa ki nga Whenua Maori, runga $i$ aus whenus me tuku hei hanga rori i runga i aua whenua.

“9. Ko nga whenua katoa e wehea ana mo nga rori me whakatan ki te Karguna.

“10. Ko nga whenua katoa e hiahiatia ana mo nga rori me nga rerewe me era atn mabi nunni ka ahei te tukn ntu kore $7 \mathrm{i}$ tena ropu takiwa kamupani ranei e hanga ana $i$ ana rerewe. $i$ ana mahi nunui ranei.

"11. Ka ahei te wehe etahi rahui hei painga mo te katoa pera ano me nga rahui i etahi atu wahi o te koroni.

E te Tumarki tekau ma ono nga pire a te Kawanatanga e mai nei $i$ roto $i$ taku ringa $\theta \mathrm{pa}$ ana $\mathrm{ki}$ nge whenua Maori a ro te A tua anake e mohio ana whia ranei kei muri. I patai atu ano ahan i tera po he aha te take i kore ai te Kawanatanga e tango i taku Pire hei riiwhi mo enei tini Pire Whenua Mari a te Kawanatanna ma te pera haki e koro ai e moumoutia te té pera hor taku tukunga i toku Pire ki to hui Maori i a Pepuere lo taki to har a Pepure kua hor nei ko Patara te kawhizo a kihai ia whake li tak Pire. I he to whakahaere o a matou whenua i raro i nga ture ki te whakaiti $i$ te maha o ana Pire ki te whakaiti i te maha o ana Pire erangi e whakamaha mai ana a e nui
haere ana $i$ nga tau katoa. Ko etahi haere ana i nga tau katos. Ko etahi tangate e mea ana he tangata noa nei a Tawhia erangi o riro ana ho painga i iaia i runga $i$ te Ture. Mehemea o hamene ana ia i nga tangata ino te pokanoa o te haere ki runga i tona whenna tera is e wiini i runga i te Ture. E penei ana hoki nga kupu o te Tiriti o Waitangi. E whakapumautia ana $e$ te Kuini o Ingarangi ki nga rangatira me nga iwi o Niu 'lireni me o ratou hapume ia tangata o ratou te tino mane ki o ratou whenus me raton ugahere ratou mahinga ila o ratou nahere mea mau ana li a raton bi is tangata rato pena a no te roa me to ratoo biahia ki

\section{Nga Korero Paremete}

